\title{
Selection of a Form
} for Fixation of lodine-129
L. L. Burger
R. D. Scheele
K. D. Wiemers

December 1981

Prepared for the U.S. Department of Energy under Contract DE-AC06-76RLO 1830

Pacific Northwest Laboratory Operated for the U.S. Department of Energy by Battelle Memorial Institute 
This report was prepared as an account of work sponsored by the United States Government. Neither the United States nor the Department of Energy, nor any of their employees, nor any of their contractors, subcontractors, or their employees, makes any warranty, express or implied, or assumes any legal liability or responsibility for the accuracy. completeness or usefulness of any information, apparatus, product or process disclosed, or represents that its use would not infringe privately owned rights.

The views, opinions and conclusions contained in this report are those of the contractor and do not necessarily represent those of the United States Government or the United States Department of Energy.

\author{
PACIFIC NORTHWEST LABORATORY \\ operated by \\ BATTELLE \\ for the \\ UNITED STATES DEPARTMENT OF ENERGY \\ under Contract DE-AC06-76RLO 1830
}

Printed in the United States of America

Available trom

National Technical information Service

United States Department of Commerce

5285 Port Royal Road

Springtield, Virginia 22151

NTIS Price Codes

Microtiche $A 01$

Printed Copy

Pages Price Codes

$001.025 \quad \mathrm{~A} 02$

026-050 $\mathrm{A03}$

051-075 A04

076-100 A05

107-125 A06

$126-150 \quad$ A07.

$157.175 \quad A 08$

$176.200 \quad$ A09

$201-225 \quad A 010$

226-250 A011

251-275 A012

276-300 A013 
SELECTION OF A FORM FOR:

FIXATION OF IODINE-129
L. L. Burger
R. D. Scheele
K. D. Wiemers

December 1981

Prepared for

the U.S. Department of Energy

under Contract DE-AC06-76RLO 1830

Pacific Northwest Laboratory

Richland, Washington 99352 


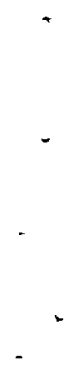




\section{SUMMARY}

This report summarizes work on the selection of an ${ }^{129}$ I disposal form. Iodine compounds have been screened on the basis of solubilities, thermal stabilities, cost and avalability, toxicity of the cation, and the thermodynamic resistance to oxidation and hydrolysis, and leaching of that compound in portland type III cement. Also considered were iodine capture technology, disposal criteria or guidelines, and the disposal site/strategy.

The recommended iodine fixation forms, based on their leach resistance and chemical stability and contingent on the disposal strategy/site and capture technique, are silver iodide in cement and barium, calcium, or strontium, and mercuric iodates in cement. Iodine sodalite appears promising and merits further study.

If compatible with disposal requirements, the recommended forms for Mercurex and Iodox are insoluble iodates in cement and for silver sorbents the sorbents in cement or $\mathrm{AgI}$ in cement. Conversion between the different oxidation states of iodine is feasible but complicates the iodine treatment.

For the different disposal strategies, isotopic dilution or ocean disposal has the least stringent disposal form requirements. Any of the recommended forms should be suitable with proper site selection. Isolation in a geologic repository for thousands of years requires the disposal form to be thermally and chemically stable and resistant to leaching at elevated temperatures. Probably the "best" form studied for isolation is silver iodide in cement. For extraterrestrial disposal, the disposal form may have to withstand reentry impact and surface disposal in the event of an aborted mission; this assumes the capsule is not recovered. Thus the primary containment barrier is critical. The suqgested iodine form for space disposal is a heavy metal iodide.

Although silver iodide appears to be the "best" disposal form, consideration should be given to its value as an irreplaceable resource. 
SUMMARY.

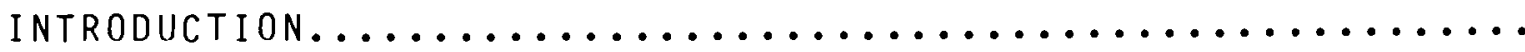

TECHNOLOGY FOR CAPTURE OF 129 I .................... 7

MERCUREX............................ 7

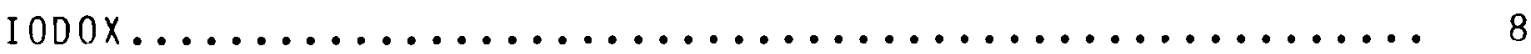

SOLID SORBENTS.......................... 8

CAUSTIC SCRUBS........................... 8

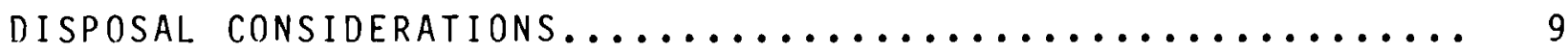

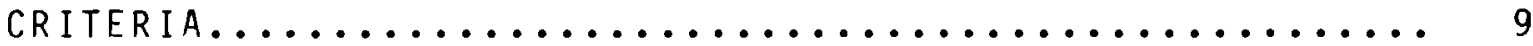

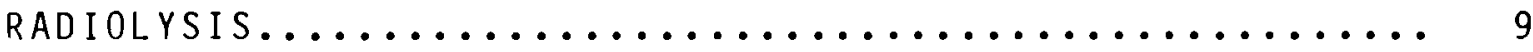

DISPOSAL STRATEGY........................... 10

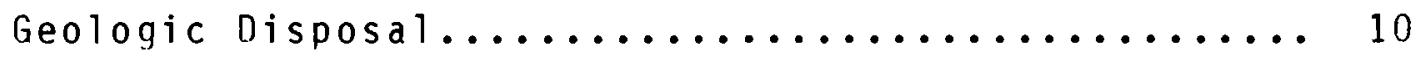

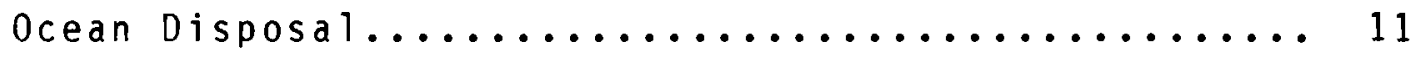

Extraterrestrial Disposal ................... 12

SELECTION OF A STORAGE/DISPOSAL MATERIAL.............. 13

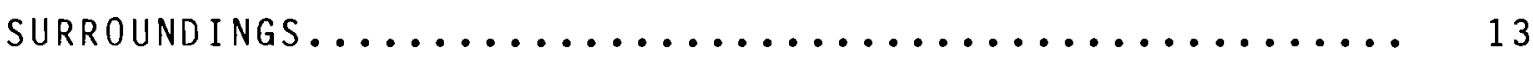

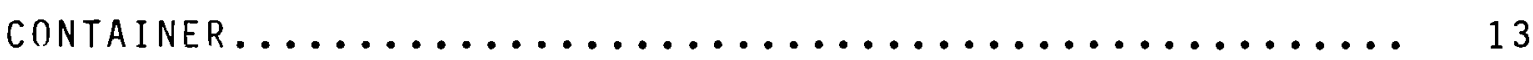

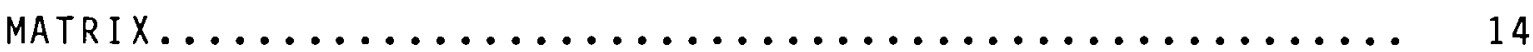

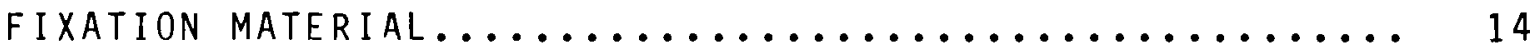

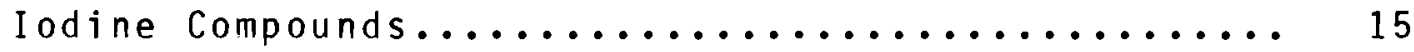

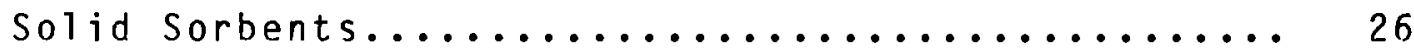

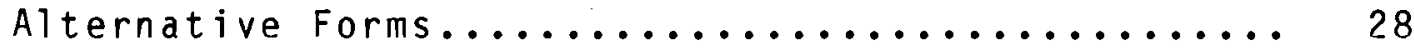

COST AND AVAILABILITY.......................... 31

LEACH RESISTANCE ............................ 35 
Contents (continued)

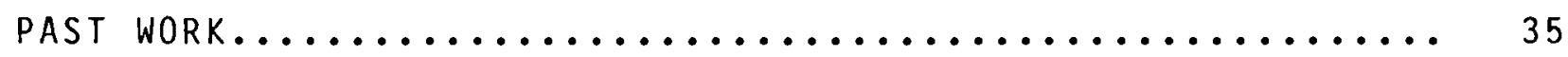

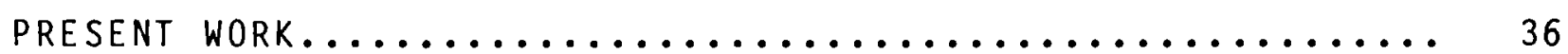

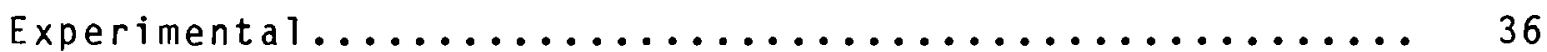

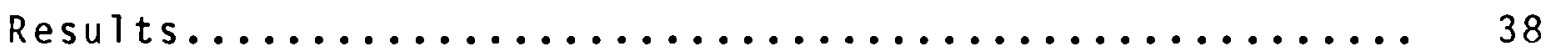

ACKNOWLEDGMENTS............................. 47

REFERENCES............................... 49 


\section{FIGURES}

1. Static Leach Test of AgI in Portland Type III Cement, $0.8 \mathrm{mmol} \mathrm{AgI} / \mathrm{g}$ Dry Cement (Distilled Water Leachate)............

2. Simulated Dynamic Leach Test of AgI in Portland Type III

Cement, $0.8 \mathrm{mmol} \mathrm{AgI} / \mathrm{g}$ Dry Cement (Cement-Equilibrated

Distilled Water Leachate)

3. Static Leach Test of $\mathrm{Ba}\left(\mathrm{IO}_{3}\right)_{2}$ in Portland Type III Cement, $0.4 \mathrm{mmol} \mathrm{Ba}\left(\mathrm{IO}_{3}\right)_{2} / \mathrm{g}$ Dry Cement (Distilled Water, River Water,

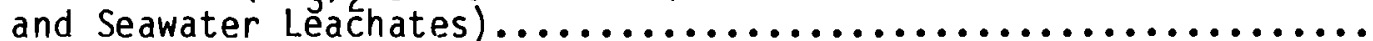

4. Static Leach Test of $\mathrm{Hg}\left(\mathrm{IO}_{3}\right)_{2}$ in Portland Type III Cement, $0.4 \mathrm{mmol} \mathrm{Hg}\left(\mathrm{IO}_{3}\right)_{2} / \mathrm{g}$ Dry Cement (Distilled Water, River Water, and Seawater Leachates).

5. Static Leach Test of $\mathrm{Ca}\left(\mathrm{IO}_{3}\right)_{2}$ in Portland Type III Cement, $0.4 \mathrm{mmol} \mathrm{Ca}\left(\mathrm{IO}_{3}\right)_{2} / \mathrm{g}$ Dry Cement (Distilled Water Leachate)........ 4

6. Modified Dynamic Leach Test of $\mathrm{Ba}\left(\mathrm{IO}_{3}\right)_{2}$ in Portland Type III Cement, $0.4 \mathrm{mmol} \mathrm{Ba}\left(\mathrm{IO}_{3}\right)_{2} / \mathrm{g}$ Dry Cement (Distilled

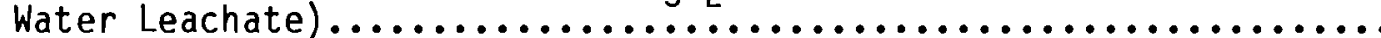

7. Static Leach Test of $\sim 370 \mathrm{mg} \mathrm{I/g} \mathrm{PbX}$ in Portland Type III Cement, $1 \mathrm{mmol} \mathrm{I} / \mathrm{g}$ Dry Cement $+\mathrm{PbX}$ (Distilled Water Leachate)

8. Static Leach Test of $150 \mathrm{mg} \mathrm{I/g} \mathrm{AgZ} \mathrm{in} \mathrm{Portland} \mathrm{Type}$ III Cement, $0.8 \mathrm{mmol} \mathrm{I} /(\mathrm{g}$ Dry Cement $+\mathrm{AgZ}$ ) (Distilled Water Leachate).

9. Simulated Dynamic Leach Test of $150 \mathrm{mg} \mathrm{I/g} \mathrm{AgZ} \mathrm{in} \mathrm{Portland}$ Type III Cement, $0.8 \mathrm{mmol}$ I/(g Dry Cement + AgZ) (Distilled Water Leachate)

10. Static Leach Test of Iodine Sodalite, $1.5 \mathrm{mmol} \mathrm{I} / \mathrm{g}$ (Distilled Water Leachate) 


\section{TABLES}

1 Solubility Data for Iodides............................... 16

2 Solubility Data for Iodates............................. 17

3 Physical and Thermodynamic Properties of

Low-Solubility Iodide Compounds Plus Iodine and Hydrogen Iodide...

$4 \quad$ Physical and Thermodynamic Properties of

Low-Solubility Iodates................................ 22

5 Thermal Behavior of Iodides............................. 23

5 Thermal Behavior of Iodates................................ 24

7 Vapor Pressures of Metal Iodides......................... 25

8 Cost and Availability Data for

Candidate Iodine Fixation Materials..................... 32

9 Typical Characteristics of

Iodine-Cement Monoliths.............................. 37 


\author{
L. L. Burger \\ R. D. Scheele \\ K. D. Wiemers
}

\title{
INTRODUCTION
}

Three isotopes of iodine, 127,129 , and 131, are among the maior fission products from nuclear fuels. Before the spent fuel is normally processed, the ${ }^{131} \mathrm{I}, t_{1 / 2}=8$ days, will have decayed to a negligible level leaving only the long half-life ${ }^{129} \mathrm{I}, \mathrm{t}_{1 / 2}=1.6 \times 10^{7}$ yr as a potential risk if released to the environment. The quantity involved is about one $\mathrm{Ci}$ per GWe-yr (about $7 \mathrm{~kg}$ ) for LWR fuels. Published regulations would limit the amount of ${ }^{129_{I}}$ discharged to the environment to $5 \mathrm{mCi} / \mathrm{GWe}-\mathrm{yr}$ (40 CFR 190 1977) and set limits for ${ }^{129} \mathrm{I}$ in air, $2 \times 10^{-11} \mathrm{Ci} / \mathrm{m}^{3}$, and in drinking water $6 \times 10^{-8} \mathrm{Ci} / \mathrm{m}^{3}(10 \mathrm{CFR} 20$ 1978). Current revisions of 40 CFR 190 may set still other standards.

Considerable technology is available for removing iodine from aqueous and gaseous streams and converting it to forms for storage and/or disposal. Reviews of removal methods for iodine are provided in two Oak Ridge National Laboratory (ORNL) publications (Holladay 1979; Jubin 1979). A brief technology assessment of ${ }^{129}$ I control in a reprocessing plant is contained in a PNL document (Burger and Burns 1979). A recent survey of radioiodine removal in nuclear facilities has been prepared by the International Atomic Energy Agency (IAEA 1980).

The present report discusses the properties of potential fixation materials with the aim of providing a basis for choosing storage or disposal forms for ${ }^{129}$ I. It must be mentioned that no governmental criteria for either storage or disposal have been defined. Thus, for preliminary screening, considerable latitude in the value of parameters such as leach rate and thermal stability may be permitted. 


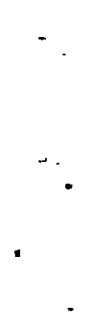

$\therefore$ 


\section{CONCLUSIONS}

Our studies have shown that several iodine forms are potential candidates for use as a fixation form for ${ }^{129}$ I, contingent upon the disposal environinent/strategy. Several iodides and iodates were screened for their solubility, thermal stability, resistance to oxidation and hydrolysis, cost and availability, and the iodine leach rate when incorporated into cement.

Also influencing the final iodine fixation form are the likely iodine products from the various gaseous iodine capture technologies. Mercurex and Iodox produce iodates. The silver-containing solid sorbents loaded with iodine are themselves products; as an option, however, with silver zeolites the iodine can be stripped as hydrogen iodide and converted to an insoluble iodide or trapped on a different metal zeolite. Lead zeolite had been suggested, but our studies have shown lead zeolite to be a poor fixation form. For Mercurex and Iodox the iodate is the preferred form, and for solid sorbents the sorbents themselves or an iodide are the preferred forms.

Our leaching studies on iodides in cement have shown that silver iodide is the only acceptable iodide. Copper and lead iodides hydrolyzed in the high $\mathrm{pH}$ environment of the cement and exhibited high leach rates. Copper iodide might be acceptable in a medium which is both reducing and neutral. Thallium iodide, the only other potentially stable iodide in cement, was rejected on toxicity grounds. Silver iodide in cement had the lowest leach rate of all iodine forms tested.

Leaching studies on iodates in cement showed nearly equivalent leaching between barium, calcium, strontium, and mercuric iodates. Because of sulfate ion in cement the lower solubility of barium and strontium iodates, compared to calcium iodate, is not effective in reducing the leach rate. Mercuric iodate has a still lower solubility, but in the high pH of the cement its behavior is no better than the alkaline earth iodates. Because of costs calcium is probably preferred over the others, depending, of course, on its compatibility with precursor processes. Assuming constant water contact, the expected leach times for these materials vary from a few hundred to a few thousand years after the containment is breached. The use of silver iodide in cement should extend the time by a factor of 100 or more. 
The simulated dynamic leach study on iodine-loaded silver mordenite in cement showed it to be intermediate between silver iodide and the iodates, while the static test showed equivalent behavior to the iodates.

Because of its high leach resistance and chemical stability, silver iodide is the most attractive iodine fixation form; however, silver is an expensive, valuable, and scarce resource. For certain purposes, such as photography and some electrical systems, there is no substitute and the demand exceeds the known reserves. Others point out, however, that the total silver required for iodine disposal is insignificant compared to that used in industry. If silver must be used, silver iodide--not silver sorbents--is the recommended form because its silver utilization is $100 \%$.

To prevent release during shipping and predisposal storage, additional coatings can be applied, although a steel drum may be adequate. For disposal and to prevent the high initial leach rate seen at the beginning of the leach studies, a second protective layer of cement would provide adequate temporary prevention of release.

of the potential disposal sites, dispersion in the oceans has the fewest restrictions on the iodine fixation form. The stability and solubility requirements are only moderate; the only requirement is that the dispersion time is less than or equal to the release time. All of the suggested candidates listed above may be used; in fact, given the right site, a very soluble form like calcium iodide could be used. Silver is not our choice for ocean disposal because of its value as a resource.

The stability and leaching considerations for isolation in a dry repository are much more critical because of the long half-life of ${ }^{129} \mathrm{I}$. For time periods comparable to the radioactive decay time, terrestrial disposal must be considered as dispersal because of geologic phenomena. Any release must therefore be at harmless concentrations. As has been noted, none of the iodine compounds has both high chemical stability and high leach resistance except perhaps silver iodide. Thus silver iodide in cement may be the best form. Next may be the group II iodates.

The requirements on the form would be the most stringent for extraterrestrial disposal. In the event of a transportation accident iodine retention would depend entirely on the primary barrier. Thus, the disposal 
form must meet or exceed the requirements for disposal in a geologic repository or in the ocean.

There are potential alternative forms. Preliminary work with sodalite indicates very good leach resistance comparable to that of AgI in cement. The use of composites with particles protected by a primary coating and mixed with cement is also a possibility. The use of bitumen or synthetic organic polymers will undoubtedly give better short-term resistance to leaching than does cement, but these materials cannot be relied upon for very long periods of time. Implantation by sputtering into an inert matrix has been considered. It would probably be a difficult and costly process. Glasses are another possibility, but suitable materials have not yet been identified. 


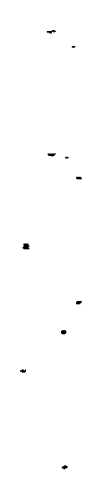


TECHNOLOGY FOR CAPTURE OF ${ }^{129}$ I

In the fuel cycle the iodine release point is the off-gas streams from the fuel reprocessing plant. Iodine removal from these streams has recently focused on three techniques: (1) mercuric nitrate-nitric acid scrubbing (Mercurex), (2) scrubbing with hyperazeotropic (>20 M) nitric acid (Iodox), and (3) sorption on solid media. Caustic scrubbing, used in early processing activities, is still considered a viable process.

These processes have been reviewed in many reports, e.g., Mercurex (Holladay 1979; Stromatt 1958; Yarbro et al. 1969), Iodox (Holladay 1979; Ginnow and Clark 1978; Collins and Benker 1979), gels and oxide solids (Jubin 1979; Holladay 1979; Ackley and Combs 1973; Gal et al. 1974; Wilhelm and Schuettelkopf 1973), and zeolites (Jubin 1979; Holladay 1979; Pence et al. 1971; Staples et al. 1976). Trapping of iodine species with silver-nitrate impregnated amorphous silica has been studied extensively in Europe using product $A C-6120^{\circledR}$ developed by Wilhelm and coworkers (Wilhelm and Schuettelkopf 1973). Good results using a commercial silica gel impreqnated with about $6.5 \%$ silver-nitrate have recently been reported by Schwarzbach and Hladik (1980).

MERCUREX

The Mercurex process uses a mercuric nitrate-nitric acid solution to complex the iodine. To separate the iodine, reduce the mercury requirements, and eliminate disposal of large quantities of mercury with the iodine, procedures have been developed that use electrolytic oxidation (Scheele 1978a) or nitric acid oxidation (Yarbro et al. 1969; Partridge and Bosuego 1979) to separate the iodine as $\mathrm{Hg}\left(\mathrm{IO}_{3}\right)_{2}$. If $\mathrm{Hg}\left(\mathrm{IO}_{3}\right)_{2}$ is not a suitable iodine disposal form, metathesis could be used to produce $\mathrm{HgO}$ and $\mathrm{NaIO}_{3}$, with subsequent conversion to an insoluble metal iodate. However, the steps, which would most likely be batch type, are slow and the separations of solids difficult.

AC6120@. Registered trademark of Süd Chemie A.G., Munich, Germany. 
$\underline{\text { IODOX }}$

In the Iodox process the hyperazeotropic nitric acid oxidizes the iodine to iodic acid, which is easily converted to an insoluble iodate. The iodine products of the Iodox process are iodic acid or, with additional processing, an insoluble iodate.

\section{SOL ID SORBENTS}

For solid sorbents the material itself can be the final product. With silver zeolites, which have received much attention in recent years, an alternative is to remove the iodine by treatment with hydrogen and reabsorb it on lead zeolite (Thomas et a 1. 1977). Indications are, however, that PbXI is not a very stable material and may not be a good storage medium (Scheele 1980). A different approach is to trap the HI in water and convert it to a metal iodide or iodate. It will be seen that iodates are often preferable to iodides for storage forms. Conversion of iodide to iodate introduces some problems: elemental iodine is an intermediate, and volatilization must be avoided. Electrochemical oxidation shows some promise, and oxidation with ozone is possible in alkaline solution (Scheele 1978a,b). Oxidation with chlorine is easily carried out, but the reagent is not compatible with the normal process equipment.

\section{CAUSTIC SCRIJBS}

If the dissolver off-gas (DOG) is washed free of most of the $\mathrm{NO}_{x}$, then caustic scrubs are convenient, well demonstrated techniques. Both $\mathrm{CO}_{2}\left({ }^{14} \mathrm{C}\right)$ and the bulk of the iodine can be removed. A disadvantage is the waste volume produced. The scrubber would be followed by a solid sorbent to remove organic iodides and the trace $\mathrm{I}_{2}$. The iodine would be precipitated as an iodide or iodate following reduction or oxidation. 
DISPOSAL CONSIDERATIONS

\section{CRITERIA}

No criteria exist for the storage or disposal of ${ }^{129}$ I. Therefore there is no quantitative measure of the suitability of a process, a storage or disposal form, or a disposal site. Suggestions for determining such criteria have been discussed in another report (Burger 1980).

Guidelines have been suggested by the Environmental Protection Agency (EPA) for limiting the exposure from fuel cycle operations. The requlations would limit the amount of ${ }^{129} \mathrm{I}$ discharged to the environment to $5 \mathrm{mCi} / \mathrm{GWe}-\mathrm{yr}$ (40 CFR 190) and set limits for ${ }^{129} \mathrm{I}$ in air $2 \times 10^{-11} \mathrm{Ci} / \mathrm{m}^{3}$, and in drinking water $6 \times 10^{-8} \mathrm{Ci} / \mathrm{m}^{3}$ (10 CFR 201978 ). The $5 \mathrm{mC} i$ release limit implies that about $4 \times 10^{-3}$ of the ${ }^{129}$ I can be discharged.

Although it is felt that a retention factor, RF, of $10^{3}$ can be achieved at the reprocessing plant, when one considers the many paths of iodine and the possibility of accidental discharges, an RF of $10^{2}$ is probably more realistic. However, under the EPA proposed quidelines, an RF of about 220 is required and no release is then permitted on storage or disposal. An equally reasonable philosophy would state that since the loss at the reprocessing plant may vary up to $1 \%$, then it makes little sense to restrict losses on storage to less than that. A $1 \%$ loss over an isolation period of $10^{4} \mathrm{yr}$ is $10^{-6}$ fraction per annum which can be compared to the radioative decay rate of $4.4 \times 10^{-8} \mathrm{yr}^{-1}$. The figure may be meaningless since $10^{-6}$ per year would be exceedingly difficult to measure. It is also meaningless to consider radioactive decay as a factor, and any form of storage may--over a period of a few half-lives--become dispersal because of geologic phenomena. Thus the concept of isolation implies dispersion at an acceptably high dilution.

\section{RADIOLYSIS}

A factor in selecting a fixation form for any radioisotope is possible radiation damage. Iodine-129 emits a low energy $150 \mathrm{keV}^{-} \beta$ particle and a 38 $\mathrm{keV} \gamma$, and has a half-1ife of $1.6 \times 10^{7} \mathrm{yr}$. 
The radiation effects must be considered even though the activity of ${ }^{129}$ I is almost negligible over normal observation time. Over the long periods required for the isolation strategy the damage will accumulate. Using a decay constant of $1.38 \mathrm{E}-15 \mathrm{~s}^{-1}$ and an average energy of $60 \mathrm{keV}$, the energy deposited is about $10^{22} \mathrm{eV} / \mathrm{kgI}-\mathrm{yr}$. For a $\mathrm{G}$ value of 1.0 for the matrix and $10 \%$ iodine loading, $2 \%$ of the matrix would be destroyed in $10^{4} \mathrm{yr}$. This could be considered serious damage.

W. E. Clark and W. B. Howerton (1980) evaluated radiolytic reduction of iodate as $\mathrm{Ba}\left(\mathrm{IO}_{3}\right)_{2}$ in cement using a ${ }^{60}$ Co source. They found that in $1000 \mathrm{yr}$ $0.21 \%$ of the iodate would be reduced to iodide. Barium iodide is much more soluble than barium iodate; thus the disposal form has been degraded.

Long-time storage implies that consideration be given to choosing both an iodine compound and a matrix material that are reasonably stable towards radiation damage. Radiolysis is another element in the dispersal phenomenon.

\section{DISPOSAL STRATEGY}

Four basic disposal strategies exist: (1) geologic disposal-long-term dry isolation, (2) isotopic dilution in the ocean, (3) extraterrestrial, and (4) transmutation. These have been discussed in several reports: Rieck and Fruchter (1975), Burns and Defield (1978), IAEA (1980), Burger (1980). Options 3 and 4 are not likely to be chosen. Option 3 is considered briefly here, but the main emphasis is on strategies 1 and 2. With these two the choice has an important impact on the fixation form because it will dictate allowable leach rates and the required thermal stability.

$\underline{\text { Geologic Disposal }}$

An early concept of geologic disposal included "...the basic requirement for any geologic environment to be suitable for disposal of radioactive waste is the capability to safely contain and isolate the emplaced radioactive material until decay has reduced the radioactivity to nonhazardous levels" (Schneider and Platt 1974). For iodine-129 this would be $10^{8} \mathrm{yr}$, impossibly long considering normal geologic changes. However, if we use the IAEA definition of isolation, "...the segregation of radionuclides from the human environment and the restriction of their release in unacceptable quantities or 
concentrations...," then dispersion or dilution is acceptable. Geologic disposal, whether in granitic, argillaceous or salt formations, is feasible. The important point is that harmless concentrations (or presumably harmlessly smal1 ${ }^{129} \mathrm{I} /{ }^{127}$ I ratios) will reach man's environment. This will be governed primarily by the water leach rate, and a minimum value must be achieved.

If the site is a salt cavern, leakage effects could be mitigated by isotopic iodine dilution. However, even if we assume an iodine/chlorine ratio in the salt bed to be 10 times that of seawater, $300 \mathrm{t}$ of salt $\left(10^{6} \mathrm{~m}^{3}\right.$ of saturated brine) would be required to dilute $10 \mathrm{~kg}$ (1 barrel) of ${ }^{129}$ I to a $10^{-3}{ }^{129} \mathrm{I} /{ }^{127} \mathrm{I}$ ratio. There is no guarantee that the combined water flowleach characteristics could produce even this maximum ratio. (a)

Thermal factors are also important in selecting a fixation form for this siting. Assuming $15^{\circ} \mathrm{C} / \mathrm{km}$, the temperature will be $90^{\circ} \mathrm{C}$ at $6 \mathrm{~km}$ deep. Therefore, the fixation form must be thermally stable to at least $100^{\circ} \mathrm{C}$, preferably to $250^{\circ} \mathrm{C}$. The higher temperature will also increase the leach rate.

We assume that the ${ }^{129} \mathrm{I}$ is not stored with high-level waste canisters due to their high radiation field and potentially high temperatures, which would increase the requirements on the iodine fixation form. It is also recommended that there be no mineral resources present, thus reducing the possibility of intrusion by man.

Ocean Disposal

Ocean disposal has the advantage of isotopic dilution of ${ }^{129}$ I by the natural iodine in the sea $\left(8 \times 10^{16} \mathrm{~g}\right.$ at a concentration of $\left.5 \times 10^{-7} \mathrm{M}\right)$. This lessens the requirements for leach resistance. The essential requirement is that the release rate be less than the mixing rate in the ocean. Ocean disposal is planned dispersion.

Iodine that is released from the fixation form will--over a period of a few thousand years--become mixed with the natural iodine in the ocean. Over a

(a) The $10^{-3}$ ratio is calculated as a maximum level for the human thyroid based on $75 \mathrm{mrem} / \mathrm{yr}$ dose. The actual $129 / 127$ ratios in surface water are about $10^{4}$ times lower (Burger 1980). 
final concentration of ${ }^{129}$ I or the $129 / 127$ ratio is kept at a harmless level based either on maximum permissible concentrations or on 129/127 ratios.

Dilution by the ocean of the $5.7 \times 10^{4} \mathrm{~kg}\left(10^{4} \mathrm{Ci}\right)$ of ${ }^{129}$ I that may be produced by the year 2000 (Russell 1971) would produce a concentration of $3.8 \times 10^{-14} \mathrm{~g} / \mathrm{L}\left(6.7 \times 10^{-18} \mathrm{Ci} / \mathrm{L}\right)$, or roughly $10^{-7}$ of the uncontrolled area MPC for drinking water. The $129 / 127$ ratio would be $3.7 \times 10^{-11}$, less than $10^{-8}$ of the recommended maximum for the human thyroid.

\section{Extraterrestrial Disposal}

In this strategy the disposal site is earth orbit, solar orbit, solar impact, or deep space (solar escape) (Schneider and Platt 1974). Rieck and Fruchter (1975) believe solar escape is the preferred option. Burns and Defield (1978) also indicate that solar escape is the only method which will guarantee disposal for $10^{8} \mathrm{yr}$. This strategy, as described by Burns and Defield (1978), uses technology yet to be demonstrated.

Rieck and Fruchter place stringent requirements on the fixation form as they believe that in the event of an aborted mission the control of iodine release will depend entirely upon the primary containment barrier. The capability to withstand impact and subsequent ground or sea disposal is required. Burns and Defield also indicate that the capability of recovery is required. 
SELECTION OF A STORAGE/DISPOSAL MATERIAL

Since criteria for storage or disposal of ${ }^{129}$ I are not established, a "best form or material" cannot be identified. Rather we will tabulate the pertinent factors, economic and scientific, such that choices can be made to fit the conditions identified. The choice will involve the best overall performance resulting from interaction of the fixation material, the matrix, the container, and the surroundings. However, there may be no single best option.

SURROUNDINGS

The surroundings or environment depend upon the disposal site considerations just discussed. The behavior of iodine in the surrounding material could be greatly influenced by secondary containment or backfill material. If a dry geologic formation is chosen, then it would be particularly desirable to use special backfill compounds to control the iodine dispersion. Such studies have not been made. The use of metals which form slightly soluble iodine compounds is one possibility. The relatively immobile iodine found in the top layer of soil and on plant surfaces suggests that some organic forms are quite stable and "fixed" with respect to migration. However, nothing is known about their behavior over more than a few decades. The data do suggest that at least for elemental iodine organic barriers may be of some value. Control of the oxidation state may be an important function of backfill material.

\section{CONTAINER}

The container's main role is to provide physical integrity during temporary storage and shipment. Iodine-129 is a low-specific activity radioactive material, for which shipping regulations refer only to such items as proper labeling and transportation in sole-use vehicles. A buffer material between the fixation compound and the drum could provide an additional safety factor. The conventional stainless steel container may be used for iodine; however, for disposal in deep sea sediments further studies may show that 
stainless is unnecessary. A recent IAEA document describes a concreteenclosed steel drum designed for sea disposal (IAEA 1981).

MATRIX

A matrix material in which to encapsulate the chosen iodine fixation compound for storage, transportation, or disposal purposes is desirable regardless of the management mode chosen; several alternatives exist, portland cement, glasses, plastics, and bitumen.

Portland cement is an obvious choice on the basis of the cost and convenience. In the presence of water, however, hydrolysis reactions promoted by the cement's high $\mathrm{pH}$ cause many of the potential fixation compounds to decompose. These reactions are discussed further in the sections on fixation compounds and leaching.

Glasses are a possibility and several are being examined at Rennes University in France. No results have been published. Plastics would provide a temporary protection. Bitumen, more resistant than most synthetic polymers, is another possibility. The latter two should provide lower initial leach rate, but the long-term stability of organic polymers is not good.

Radiation damage is seldom considered for ${ }^{129}$ I compounds since the activity is almost negligible over normal observation time. As noted earlier, over long periods of time required for the isolation strategy the damage will accumulate and for a $G$ value of 1.0 (one molecule decomposed per $100 \mathrm{eV}$ energy absorbed) about $2 \%$ would be destroyed in $10^{4} \mathrm{yr}$. Actual $\mathrm{G}$ values may be lower but still high enough to cause serious damage in organic materials and many glasses.

\section{FIXATION MATERIAL}

The fixation material may be a simple iodine compound such as the metal iodides or iodates or may consist of the iodine sorbed into a solid support. The following discussion on potential fixation materials will cover those properties pertinent to the selection of a fixation material. Detailed information concerning leachability will follow. 
Iodine Compounds

Tables 1 through 7 list data on solubility, oxidation, reduction, thermostability, vapor pressure, toxicity properties, and cost and availability of pure iodine compounds.

Behavior towards water is of prime importance. Solubility data for iodides and iodates are listed in Tables 1 and 2, respectively. Included are data for the hydrolysis product. Note that the metals $\mathrm{Bi}, \mathrm{Cu}, \mathrm{Pb}, \mathrm{Tl}$, and $\mathrm{Pd}$ have hydrolysis products an order of magnitude more insoluble than the corresponding iodides. This is assumed to be an undesirable attribute, although for very low solubility materials, e.g., $\mathrm{PdI}_{2}$ the importance diminishes. On the other hand, for lead and bismuth the problem can be serious. Silver iodide clearly emerges as the choice. No data were found for the oxy-iodides.

Of the metals listed in Table 2, no iodate data were found for Bi. For the others the iodates are somewhat more soluble than the iodides but still attractively low. There are many other slightly soluble iodates, as Table 2 shows. Note that the group II iodates are stable towards hydrolys is and moderately insoluble. Also recall that the hydrolysis product may proceed to the oxide form, which for the heavy metals is often more insoluble.

Tables 3 and 4 list pertinent physical properties and thermodynamic data along with data for $\mathrm{HI}, \mathrm{I}_{2}$, and $\mathrm{H}_{2} \mathrm{O}$. In the presence of oxygen only $\mathrm{Ag}$ and $\mathrm{Tl}$ show excellent resistance towards release of iodine. Note that $\mathrm{Bi}$ and $\mathrm{Cu}$ have iodides that are quite unstable with respect to their oxides. These two metals also form moderately stable oxy-or hydroxy-iodides, but no quantitative information was found.

One possible reaction of the iodates that needs to be mentioned is reduction. While reduction by ordinary chemical reactions does not readily occur, the possibility of anaerobic reduction involving bacterial action must be considered. We know of no data of this type, but it is conceivable that over long periods of time $\mathrm{I}^{-}, \mathrm{I}_{2}$ and organic iodides may form in such an environment. 
TABLE 1. Solubility Data for Iodides

\begin{tabular}{|c|c|c|c|}
\hline Compound & $\begin{array}{c}\text { Solubility (a) } \\
\text { Product }\end{array}$ & $\begin{array}{c}{\left[\mathrm{I}^{-}\right]} \\
\mathrm{g} \text {-atoms/L }\end{array}$ & $\begin{array}{l}{\left[\mathrm{m}^{+x}\right]} \\
\mathrm{g} \text {-atoms } / \mathrm{L}\end{array}$ \\
\hline $\mathrm{AgI}$ & $8.3 \times 10^{-17}$ & $9.1 \times 10^{-9}$ & \\
\hline $\mathrm{AgOH}$ & $2.0 \times 10^{-8}$ & & $1.4 \times 10^{-4}$ \\
\hline $\mathrm{BiI}_{3}$ & $8.1 \times 10^{-19}$ & $3.9 \times 10^{-5}$ & \\
\hline $\mathrm{Bi}(\mathrm{OH})_{3}$ & $4.0 \times 10^{-31}$ & & $3.0 \times 10^{-8}$ \\
\hline CuI & $1.1 \times 10^{-12}$ & $1.0 \times 10^{-6}$ & \\
\hline $\mathrm{CuOH}$ & $1.0 \times 10^{-14}$ & & $1.0 \times 10^{-7}$ \\
\hline $\mathrm{Hg}_{2} \mathrm{I}_{2}$ & $9.5 \times 10^{-29}$ & $9.7 \times 10^{-15}$ & \\
\hline $\mathrm{Hg}_{2}(\mathrm{OH})_{2}$ & $2.0 \times 10^{-24}$ & & $1.4 \times 10^{-12}$ \\
\hline $\mathrm{HgI}_{2}$ & $1.1 \times 10^{-12}$ & $1.3 \times 10^{-4}$ & \\
\hline $\mathrm{Hg}(\mathrm{OH})_{2}$ & $3.2 \times 10^{-13}$ & & $7.4 \times 10^{-5}$ \\
\hline $\mathrm{PbI}_{2}$ & $7.1 \times 10^{-9}$ & $2.4 \times 10^{-3}$ & \\
\hline $\mathrm{Pb}(\mathrm{OH})_{2}$ & $1.2 \times 10^{-15}$ & & $1.3 \times 10^{-5}$ \\
\hline $\mathrm{PdI}_{2}$ & $2.5 \times 10^{-23(b)}$ & $3.7 \times 10^{-8}$ & \\
\hline $\mathrm{Pd}(\mathrm{OH})_{2}$ & $1.0 \times 10^{-31}$ & & $5.8 \times 10^{-11}$ \\
\hline $\mathrm{Tl} \mathrm{I}$ & $6.5 \times 10^{-8}$ & $2.5 \times 10^{-4}$ & \\
\hline $\mathrm{TIOH}$ & 2.4 & & 1.6 \\
\hline
\end{tabular}

(a) Data from Dean 1973 except as noted.

(b) Horner 1976. 
TABLE 2. Solubility of Iodates

\begin{tabular}{|c|c|c|}
\hline Compound & $\begin{array}{l}\text { Solubility } \\
\text { Product (a) }\end{array}$ & $\begin{array}{r}{\left[\mathrm{IO}_{3}{ }^{-}\right] \text {or }} \\
{\left[\mathrm{OH}^{-}\right],} \\
\mathrm{g}-\mathrm{mole} / \mathrm{L} \\
\end{array}$ \\
\hline $\mathrm{AgIO}_{3}$ & $3.0 \times 10^{-8}$ & $1.7 \times 10^{-4}$ \\
\hline $\mathrm{AgOH}$ & $2.0 \times 10^{-8}$ & $1.4 \times 10^{-4}$ \\
\hline $\mathrm{Ba}\left(\mathrm{IO}_{3}\right)_{2} \cdot 2 \mathrm{H}_{2} \mathrm{O}$ & $1.5 \times 10^{-9}$ & $1.4 \times 10^{-3}$ \\
\hline $\mathrm{Ba}(\mathrm{OH})_{2}$ & $5.0 \times 10^{-3}$ & $2.0 \times 10^{-1}$ \\
\hline $\mathrm{Bi}\left(\mathrm{IO}_{3}\right)_{2}$ & Insoluble & \\
\hline $\mathrm{Bi}(\mathrm{OH})_{3}$ & $4.0 \times 10^{-31}$ & $3.3 \times 10^{-8}$ \\
\hline $\mathrm{Ca}\left(\mathrm{IO}_{3}\right)_{2} \cdot 6 \mathrm{H}_{2} \mathrm{O}$ & $7.1 \times 10^{-7}$ & $1.1 \times 10^{-2}$ \\
\hline $\mathrm{Ca}(\mathrm{OH})_{2}$ & $5.5 \times 10^{-6}$ & $2.2 \times 10^{-2}$ \\
\hline $\mathrm{Ce}\left(\mathrm{IO}_{3}\right)_{3}$ & $3.2 \times 10^{-10}$ & $5.6 \times 10^{-3}$ \\
\hline $\mathrm{Ce}\left(\mathrm{IO}_{3}\right)_{4}$ & $5.0 \times 10^{-17}$ & $7.0 \times 10^{-4}$ \\
\hline $\mathrm{Ce}(\mathrm{OH})_{3}$ & $1.6 \times 10^{-20}$ & $1.5 \times 10^{-5}$ \\
\hline $\mathrm{CeO}_{2}$ & $8.0 \times 10^{-37}$ & \\
\hline $\mathrm{Co}\left(\mathrm{IO}_{3}\right)_{2}$ & $1.0 \times 10^{-4}$ & $5.8 \times 10^{-2}$ \\
\hline $\mathrm{CuIO}_{3}$ & $1.4 \times 10^{-7}$ & $3.7 \times 10^{-4}$ \\
\hline $\mathrm{Cu}\left(\mathrm{IO}_{3}\right)_{2}$ & $7.4 \times 10^{-8}$ & $5.3 \times 10^{-3}$ \\
\hline $\mathrm{CuOH}$ & $1.0 \times 10^{-14}$ & $1.0 \times 10^{-7}$ \\
\hline $\mathrm{Cu}(\mathrm{OH})_{2}$ & $2.2 \times 10^{-20}$ & $3.5 \times 10^{-7}$ \\
\hline $\mathrm{Fe}\left(\mathrm{IO}_{3}\right)_{3}$ & $1.6 \times 10^{-15}$ & $6.0 \times 10^{-4}$ \\
\hline $\mathrm{Fe}(\mathrm{OH})_{3}$ & $4.0 \times 10^{-38(b)}$ & $5.9 \times 10^{-10}$ \\
\hline $\mathrm{Hg}_{2}\left(\mathrm{IO}_{3}\right)_{2}$ & $2.0 \times 10^{-14}$ & $1.4 \times 10^{-7}$ \\
\hline $\mathrm{Hg}\left(\mathrm{IO}_{3}\right)_{2}$ & $3.2 \times 10^{-13}$ & $8.6 \times 10^{-5}$ \\
\hline $\mathrm{Hg}_{2}(\mathrm{OH})_{2}$ & $2.0 \times 10^{-24}$ & $1.4 \times 10^{-12}$ \\
\hline $\mathrm{Hg}(\mathrm{OH})_{2}$ & $3.2 \times 10^{-13}$ & $7.4 \times 10-5$ \\
\hline
\end{tabular}


Table 2 (continued)

\begin{tabular}{|c|c|c|}
\hline Compound & $\begin{array}{l}\text { Solubility } \\
\text { Product (a) }\end{array}$ & $\begin{array}{c}{\left[\mathrm{IO}_{3}^{-}\right] \text {or }} \\
{\left[\mathrm{OH}^{-}\right],} \\
\mathrm{g-mole} / \mathrm{L}\end{array}$ \\
\hline $\operatorname{In}\left(\mathrm{IO}_{3}\right)_{3}$ & $1.2 \times 10^{-12}$ & $3.1 \times 10^{-3}$ \\
\hline $\operatorname{In}(\mathrm{OH})_{3}$ & $6.3 \times 10^{-34}$ & $6.6 \times 10^{-9}$ \\
\hline $\mathrm{La}\left(\mathrm{IO}_{3}\right)_{3}$ & $6.1 \times 10^{-12}$ & $2.1 \times 10^{-3}$ \\
\hline $\mathrm{La}(\mathrm{OH})_{3}$ & $2.0 \times 10^{-19}$ & $2.8 \times 10^{-5}$ \\
\hline $\mathrm{Ni}\left(\mathrm{IO}_{3}\right)_{2}$ & $1.4 \times 10^{-8}$ & $3.0 \times 10^{-2}$ \\
\hline $\mathrm{Ni}(\mathrm{OH})_{2}$ & $2.0 \times 10^{-15}$ & $1.6 \times 10^{-5}$ \\
\hline $\mathrm{Pb}\left(\mathrm{IO}_{3}\right)_{2}$ & $3.2 \times 10^{-13}$ & $8.6 \times 10^{-5}$ \\
\hline $\mathrm{Pb}(\mathrm{OH})_{2}$ & $1.2 \times 10^{-15}$ & $1.3 \times 10^{-5}$ \\
\hline $\mathrm{Pu}\left(\mathrm{IO}_{3}\right)_{4}$ & $5.0 \times 10^{-13}$ & $5.0 \times 10^{-3}$ \\
\hline $\operatorname{Sr}\left(\mathrm{IO}_{3}\right)_{2}$ & $3.3 \times 10^{-7}$ & $8.7 \times 10^{-3}$ \\
\hline $\mathrm{Sr}(\mathrm{OH})_{2}$ & $6.0 \times 10^{-5(b)}$ & $8.0 \times 10^{-2}$ \\
\hline $\operatorname{Th}\left(\mathrm{IO}_{3}\right)_{4}$ & $2.5 \times 10^{-15}$ & $1.6 \times 10^{-3}$ \\
\hline $\operatorname{Th}(\mathrm{OH})_{4}$ & $4.0 \times 10^{-45}$ & $1.7 \times 10^{-9}$ \\
\hline $\mathrm{Tl} \mathrm{IO}_{3}$ & $3.1 \times 10^{-6}$ & $1.8 \times 10^{-3}$ \\
\hline $\mathrm{TlOH}$ & $2.4^{(b)}$ & 1.6 \\
\hline $\mathrm{UO}_{2}\left(\mathrm{IO}_{3}\right)_{2}$ & $3.2 \times 10^{-8}$ & $4.0 \times 10^{-3}$ \\
\hline $\mathrm{UO}_{2}(\mathrm{OH})_{2}$ & $1.1 \times 10^{-22(b)}$ & $6.0 \times 10^{-8}$ \\
\hline $\mathrm{Zn}\left(\mathrm{IO}_{3}\right)_{2}$ & $2.0 \times 10^{-8}$ & $3.4 \times 10^{-3}$ \\
\hline $\mathrm{Zn}(\mathrm{OH})_{2}$ & 1. $2 \times 10^{-17}$ & $2.9 \times 10^{-6}$ \\
\hline
\end{tabular}

(a) Dean 1973 .

(b) Seidel1 1953 . 
TABLE 3. Physical and Thermodynamic Properties of Low-Solubility Iodide Compounds Plus Iodine and Hydrogen Iodide

$\begin{array}{lcc}\text { Compound } & \begin{array}{c}\text { Melting(a) } \\ \text { Point, }{ }^{\circ} \mathrm{C}\end{array} & \begin{array}{c}\text { Boiling or }(a) \\ \text { Decomposition } \\ \text { Point, }{ }^{\circ} \mathrm{C}\end{array} \\ \mathrm{AgI} & 559 & 1505 \\ \mathrm{Ag} & & \\ \mathrm{Ag}_{2} \mathrm{O} & & \end{array}$

409

$542 \mathrm{dec}$

$\begin{array}{r}-\Delta G_{f}(b) \\ \mathrm{kcal} / \mathrm{mole} \\ \hline\end{array}$

$\vec{\omega} \quad \mathrm{CuI}$

$\mathrm{Cu}_{2} \mathrm{O}$

$\mathrm{CuO}$

$\mathrm{Hg}_{2} \mathrm{I}_{2}$

$\mathrm{HgI}_{2}$

$\mathrm{Hg}$

$\mathrm{HgO}$

$\mathrm{I}_{2}$

$\mathrm{H}_{2} \mathrm{O}$
1207

588

290

250

354

114

$-51$
15.8

0

2.59

35.6

0

17.2
$-\Delta H_{f}(b)$

$\mathrm{kcal} / \mathrm{mole}$

14.8

0

7.3

36.0

0

136.4

16.2

0

40.7

37.2

28.46

25.2

0

21.7

0

$-6.3$

$-57.8$ $s$ (b)

$\Delta G_{\mathrm{Ox}}\left(\mathrm{MI}+\mathrm{O}_{2}\right)$

27.6

10.2

29.1

53.7

13.6

36.2

23.1

7.97

22.21

10.18

57.67

$-0.70$

40.8

4.85

18.17

16.8

27.8

49.35

45.106

14.6

$-15.3$ $-1.05,-14.0(c)$

$-0.38$

54.6 
TARLE 3 (continued)

\begin{tabular}{|c|c|c|c|c|c|c|}
\hline Compound & $\begin{array}{l}\text { Melting (a) } \\
\text { Point, }{ }^{\circ} \mathrm{C} \\
\end{array}$ & $\begin{array}{l}\text { Boiling or (a) } \\
\text { Decomposition } \\
\text { Point, }{ }^{\circ} \mathrm{C} \\
\end{array}$ & $\begin{array}{c}-\Delta G_{f}(b) \\
k c a l / m o l e\end{array}$ & $\begin{array}{l}-\Delta H_{f}(b) \\
k c a l / m o l e\end{array}$ & $\begin{array}{c}S(b) \\
\text { cal/mole-deg }\end{array}$ & $\begin{array}{l}\Delta G_{O X}\left(M I+O_{2}\right) \\
\mathrm{kcaY} / \mathrm{g} \text {-atom I }\end{array}$ \\
\hline $\mathrm{bI}_{2}$ & 407 & 8.62 & 41.4 & 41.82 & 41.87 & -1.85 \\
\hline $\mathrm{Pb}$ & & & 0 & 0 & 15.48 & \\
\hline $\mathrm{b} 0$ & & & 45.1 & 57.1 & 15.6 & \\
\hline $\mathrm{dI}_{2}$ & & & 15.0 & 15.2 & 36 & -2.35 \\
\hline $\mathrm{Pd}$ & & & 0 & 0 & 9.06 & \\
\hline $\mathrm{Pd} 0$ & & & 19.7 & 21.7 & 13.4 & \\
\hline III & 440 & 845 & 30 & 29.6 & 30.5 & 13.4 \\
\hline 1 & & & 0 & 0 & 15.34 & \\
\hline $1_{2} 0$ & & & 33.1 & 40 & 32.1 & \\
\hline
\end{tabular}

\section{Vapor Pressures, Torr}

AgI $\log p=\frac{-10.250 E 03}{T}-3.52 \log T+20.09$, range $558-1505^{\circ} \mathrm{C}(d)$

$\mathrm{BiI}_{3} \log \mathrm{p}=8.170-4310 / \mathrm{T}^{(\mathrm{e})}$

CuI $\log p=\frac{-7.853 \mathrm{E} 03}{T}+8.678^{(d)}$, range 411 to $497^{\circ} \mathrm{C}$ 


\section{TABLE 3 (continued)}

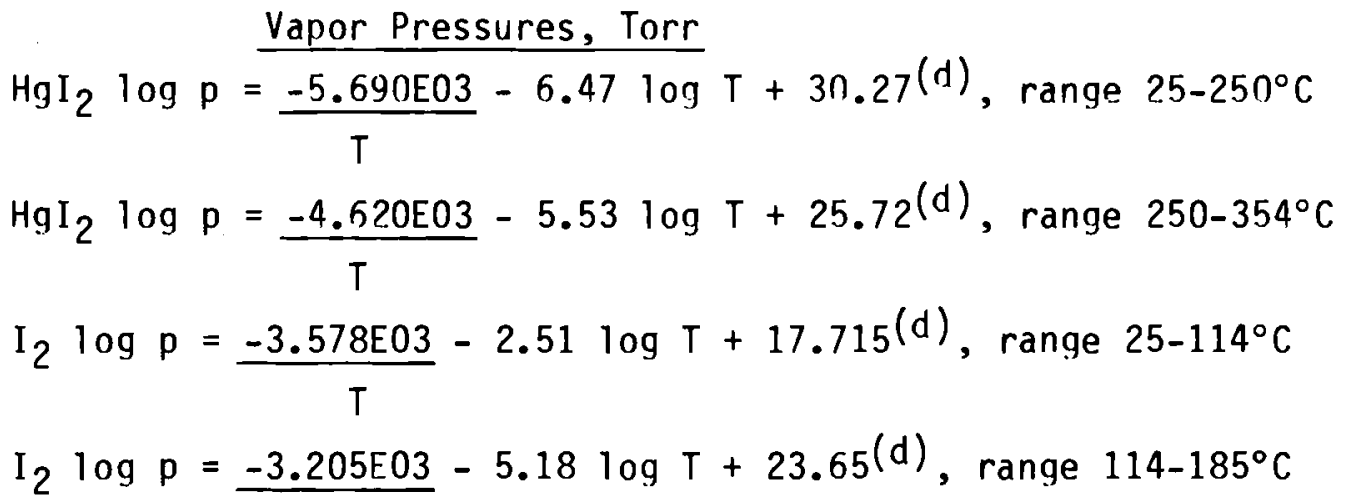

Vapor Pressures, Torr

\footnotetext{
(a) Weast 1969.

(b) Wagman et al. 1965.

(c) For the formation of $\mathrm{Cu}_{2} \mathrm{O}$ and $\mathrm{CuO}$, respectively.

(d) Barin and Knacke 1973 or Barin, Knacke, \& Kubaschewski 1977.

(e) Smith 1973.
} 
TABLE 4. Physical and Thermodynamic Properties of Low-Solubility Iodates

\begin{tabular}{|c|c|c|c|c|c|}
\hline Compound & $\begin{array}{l}\text { Melting }(a) \\
\text { Point, }{ }^{\circ} \mathrm{C} \\
\end{array}$ & $\begin{array}{l}\text { Boiling or }(\mathrm{a}) \\
\text { Decomposition } \\
\text { Point, }{ }^{\circ} \mathrm{C} \\
\end{array}$ & $\begin{array}{r}-\Delta G_{f}(b) \\
\mathrm{kcal} / \mathrm{mole}\end{array}$ & $\begin{array}{c}-\Delta \mathrm{H}_{\mathrm{f}}(\mathrm{b}) \\
\mathrm{kcal} / \mathrm{mole}\end{array}$ & $\begin{array}{c}\mathrm{s}^{(\mathrm{b})} \\
\mathrm{cal} / \mathrm{mole}-\mathrm{deg} \\
\end{array}$ \\
\hline $\mathrm{AgIO}_{3}$ & $>200$ & $410(\mathrm{dec})(\mathrm{c})$ & 22.4 & 40.9 & 35.7 \\
\hline $\mathrm{Ba}\left(\mathrm{IO}_{3}\right)_{2}$ & & dec & 206.7 & 245.5 & 59.6 \\
\hline $\mathrm{Ba}\left(\mathrm{IO}_{3}\right)_{2} \cdot \mathrm{H}_{2} \mathrm{O}$ & & $200\left(\mathrm{H}_{2} \mathrm{O}\right)$ & 263.9 & 316 & 71 \\
\hline \multicolumn{6}{|l|}{$\mathrm{Bi}\left(\mathrm{IO}_{3}\right)_{2}$} \\
\hline $\mathrm{Ca}\left(\mathrm{IO}_{3}\right)_{2}$ & & 540 (dec) & 200.6 & 239.6 & 55 \\
\hline $\mathrm{Ca}\left(\mathrm{IO}_{3}\right)_{2} \cdot \mathrm{H}_{2} \mathrm{O}$ & & & & 309.1 & \\
\hline $\mathrm{Ca}\left(\mathrm{IO}_{3}\right)_{2} \cdot 6 \mathrm{H}_{2} \mathrm{O}$ & & & 542.0 & 664.6 & 108 \\
\hline \multicolumn{6}{|l|}{$\begin{array}{l}\mathrm{Ce}\left(\mathrm{IO}_{3}\right)_{3}{ }^{(\mathrm{d})} \\
\mathrm{Ce}\left(\mathrm{IO}_{3}\right)_{4}{ }^{(\mathrm{d})}\end{array}$} \\
\hline \multicolumn{6}{|l|}{$\mathrm{Cu}\left(\mathrm{IO}_{3}\right)_{2}$} \\
\hline $\mathrm{Cu}\left(\mathrm{IO}_{3}\right)_{2} \cdot \mathrm{H}_{2} \mathrm{O}$ & & $\operatorname{dec}$ & 112.0 & 165.4 & 59.1 \\
\hline $\mathrm{I}_{2} \mathrm{O}_{5}$ & & 275 (dec) & & 37.78 & \\
\hline \multicolumn{6}{|l|}{$\mathrm{La}\left(\mathrm{IO}_{3}\right)_{3}{ }^{(\mathrm{d})}$} \\
\hline $\mathrm{Hg}_{2}\left(\mathrm{IO}_{3}\right)_{2}$ & & 250 (dec) & 46.8 & & \\
\hline $\mathrm{Hg}\left(\mathrm{IO}_{3}\right)_{2}$ & & & 41.2 & & \\
\hline $\mathrm{Ni}\left(\mathrm{IO}_{3}\right)_{2}$ & & & 78.0 & 116.9 & 51 \\
\hline $\mathrm{Pb}\left(\mathrm{IO}_{3}\right)_{2}$ & & 300 (dec) & 84.0 & 118.4 & 74.8 \\
\hline $\operatorname{Sr}\left(\mathrm{IO}_{3}\right)_{2}$ & & & 204.4 & 243.6 & 56 \\
\hline $\mathrm{Sr}\left(\mathrm{IO}_{3}\right)_{2} \cdot \mathrm{H}_{2} \mathrm{O}$ & & & 260.4 & 313.2 & 66 \\
\hline $\mathrm{Sr}\left(\mathrm{IO}_{3}\right)_{2} \cdot 6 \mathrm{H}_{2} \mathrm{O}$ & & & 666.8 & 543.7 & 109 \\
\hline
\end{tabular}




\section{Table 4 (continued)}

\begin{tabular}{|c|c|c|c|c|c|}
\hline Compound & $\begin{array}{l}\text { Melting }(a) \\
\text { Point, }{ }^{\circ} \mathrm{C} \\
\end{array}$ & $\begin{array}{l}\text { Boiling or (a) } \\
\text { Decomposition } \\
\text { Point, }{ }^{\circ} \mathrm{C} \\
\end{array}$ & $\begin{array}{r}-\Delta G_{f}{ }^{(b)} \\
\mathrm{kcal} / \mathrm{mole}\end{array}$ & $\begin{array}{l}-\Delta \mathrm{H}_{f}(\mathrm{~b}) \\
\mathrm{kca} / \mathrm{mole}\end{array}$ & $\begin{array}{c}S^{(b)} \\
\text { cal/mole-deg } \\
\end{array}$ \\
\hline $\operatorname{Th}\left(\mathrm{IO}_{3}\right)_{4}(\mathrm{~d})$ & & & & & \\
\hline $\mathrm{UO}_{2}\left(\mathrm{IO}_{3}\right)_{2}$ & & 250 (dec) & & & \\
\hline $\mathrm{Zn}\left(\mathrm{IO}_{3}\right)_{2}$ & & dec & & 103.68 & \\
\hline
\end{tabular}

(a) Weast 1969 except as noted.

(b) Latimer 1956.

(c) Duval 1963.

(d) Information unavailable for compound.

TABLE 5. Thermal Behavior of Iodides

\begin{tabular}{|c|c|c|c|c|c|}
\hline Compound & $\begin{array}{l}\text { Melting } \\
\text { Point, } \\
{ }^{\circ} \mathrm{C} \\
\end{array}$ & $\begin{array}{c}\text { Boiling } \\
\text { Point, } \\
{ }^{\circ} \mathrm{C} \\
\end{array}$ & $\begin{array}{l}\text { Iodine }(\mathrm{a}) \\
\text { loss },{ }^{\circ} \mathrm{C}\end{array}$ & $\begin{array}{l}\text { Iodine } \\
\text { Loss, Our } \\
\text { Lab, }{ }^{\circ} \mathrm{C} \\
\end{array}$ & Reaction \\
\hline $\mathrm{AgI}$ & 558 & 1505 & 900 (dec) & 600, (subl) & \\
\hline $\mathrm{BiI}_{3}$ & 408.6 & & & 211 (sub1) & \\
\hline $\mathrm{BiOI}$ & & & 300 (b) & & \\
\hline CUI & & & 296 (dec) & 298(dec) & $\begin{array}{l}\mathrm{CuI}+1 / 2 \mathrm{O}_{2}+ \\
\mathrm{Cu} 0+1 / 2 \mathrm{I}_{2}(\mathrm{a})\end{array}$ \\
\hline $\mathrm{Hg}_{2} \mathrm{I}_{2}$ & & & & 111 (sub1) & \\
\hline $\mathrm{HgI}_{2}$ & & 88 (subl) & & 105 (subl) & \\
\hline $\mathrm{PbI}_{2}$ & & & 367 & & \\
\hline $\mathrm{PdI}_{2}$ & 365 & & & & \\
\hline TII I & 473 & & 380 & & \\
\hline
\end{tabular}
(a) Duval 1963
(b) Smith 1973 
TABLE 6. Thermal Behavior of Iodates

\begin{tabular}{|c|c|c|c|}
\hline Compound & $\begin{array}{l}\text { Iodine } \\
\text { loss, }{ }^{\circ} \mathrm{C}\end{array}$ & $\begin{array}{l}\text { Iodine } \\
\text { Loss, Our } \\
\text { lab, }{ }^{\circ} \mathrm{C} \\
\end{array}$ & Reaction (a) \\
\hline $\mathrm{AgIO}_{3}$ & 410 & 410 & $\mathrm{Ag}\left(\mathrm{IO}_{3}\right) \rightarrow \mathrm{AgI}+3 / 20_{2}$ \\
\hline $\mathrm{Ba}\left(\mathrm{IO}_{3}\right)_{2} \cdot \mathrm{H}_{2} \mathrm{O}$ & 476 & & $5 \mathrm{Ba}\left(\mathrm{IO}_{3}\right)_{2} \rightarrow \mathrm{Ba}_{5}\left(\mathrm{IO}_{6}\right)_{2}+4 \mathrm{I}_{2}+90_{2}$ \\
\hline $\mathrm{Ba}\left(\mathrm{IO}_{3}\right)_{2}$ & & 480 (dec) & \\
\hline $\mathrm{Bi}\left(\mathrm{IO}_{3}\right)_{3}$ & $\begin{array}{l}\text { mixed } \\
\text { results }\end{array}$ & 296 (dec) & \\
\hline $\mathrm{Ca}\left(\mathrm{IO}_{3}\right)_{2}$ & $\begin{array}{l}540-550 \\
850-855\end{array}$ & $\begin{array}{l}\text { stable } \\
\text { to } 500\end{array}$ & $5 \mathrm{Ca}\left(\mathrm{IO}_{3}\right)_{2} \rightarrow \mathrm{Ca}_{5}\left(\mathrm{IO}_{6}\right)_{2}+4 \mathrm{I}_{2}+90_{2}$ \\
\hline $\mathrm{Ce}\left(\mathrm{IO}_{3}\right)_{3}$ & & 370 & \\
\hline $\mathrm{Ce}\left(\mathrm{IO}_{3}\right)_{4}$ & & 300 & $\begin{array}{l}\text { Duval suggests mechanism analogous to } \\
\text { alkaline earth iodates. }\end{array}$ \\
\hline $\mathrm{Ce}\left(\mathrm{IO}_{3}\right)_{4} \cdot \mathrm{KIO}_{3} \cdot 8 \mathrm{H}_{2} \mathrm{O}$ & 630 & & \\
\hline $\begin{array}{l}\mathrm{Cu}\left(\mathrm{IO}_{3}\right)_{2} \\
\mathrm{Fe}\left(\mathrm{IO}_{3}\right)_{3}\end{array}$ & $440^{\circ} \mathrm{C}$ & 400 & \\
\hline $\mathrm{La}\left(\mathrm{IO}_{3}\right)_{3}$ & & 460 & \\
\hline $\mathrm{Hg}_{2}\left(\mathrm{IO}_{3}\right)_{2}$ & 175 & 175,285 & \\
\hline $\mathrm{Hg}\left(\mathrm{IO}_{3}\right)_{2}$ & & 415 (dec) & \\
\hline $\mathrm{Ni}\left(\mathrm{IO}_{3}\right)_{2}$ & & & \\
\hline $\mathrm{Pb}\left(\mathrm{IO}_{3}\right)_{2}$ & 400 & 400 & \\
\hline $\operatorname{Sr}\left(\mathrm{IO}_{3}\right)_{2}$ & 600 & $\begin{array}{l}\text { stable } \\
\text { to } 500\end{array}$ & $5 \mathrm{Sr}\left(\mathrm{IO}_{3}\right)_{2} \rightarrow \mathrm{Sr}_{5}\left(\mathrm{IO}_{6}\right)_{2}+4 \mathrm{I}_{2}+90_{2}$ \\
\hline $\operatorname{Th}\left(\mathrm{IO}_{3}\right)_{4}$ & 300 & 480 & \\
\hline $\mathrm{UO}_{2}\left(\mathrm{IO}_{3}\right)_{2}$ & & 420 & \\
\hline $\operatorname{Zn}\left(\mathrm{IO}_{3}\right)_{2}$ & & 407 & \\
\hline
\end{tabular}

(a) Duval 1963. 
A reaction of considerable importance is thermal decomposition. Tables 5 and 6 show the thermal behavior. "Decomposition temperatures" from the literature are compared to the thermogravimetric (TGA) data from our laboratory. The latter temperature data are the points at which $>1 \%$ loss occurs on the TGA curves.

Volatilization of the iodides occurs over a wide range of temperatures. Table 7 lists calculated vapor pressures for the equations given in Table 5. The iodides of bismuth and mercury may be too volatile to be useful fixation forms. Thallium iodide is borderline.

The iodates are mostly stable to $300-500^{\circ} \mathrm{C}$, at which point they produce iodides. Note that the group II iodates disproportionate but at relatively high temperatures, e.g., $550^{\circ}$ for $\mathrm{Sr}\left(\mathrm{IO}_{3}\right)_{2}$. The decomposition mechanism is not known for all metal iodates. Duval (1963) suggests that $\mathrm{Ce}\left(\mathrm{IO}_{3}\right)_{4}$ decomposes in a manner analogous to the alkaline earth iodates. The rare earth iodates are thermally very stable, and if it were not for potential release of iodine through hydrolysis, they would be good fixation forms.

TABLE 7. Vapor Pressures of Metal Iodides(a)

\begin{tabular}{|c|c|c|}
\hline Compound & \multicolumn{2}{|c|}{ Pressure, torr (K) } \\
\hline $\mathrm{HgI}_{2}$ & $0.162(400)$ & $26.8(500)$ \\
\hline $\mathrm{BiI}_{3}$ & $0.355(500)$ & $9.70(600)$ \\
\hline T1 I & $0.014(600)$ & $0.56(700)$ \\
\hline $\mathrm{PbI}_{2}$ & $0.21(700)$ & $148.0(1000)$ \\
\hline CUI & $0.0029(700)$ & $0.073(800)$ \\
\hline $\mathrm{AgI}$ & $0.19(1000)$ & \\
\hline
\end{tabular}

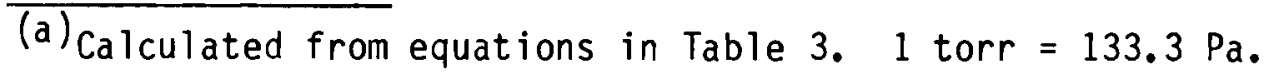


At this point toxicity can be mentioned. All heavy metals are considered toxic, and lead, mercury, and thallium can be considered hazardous. The danger is not so much from ingestion of the metal compound (the replacement of the natural human iodine level by iodine from $\mathrm{HgI}_{2}$ would introduce about $20 \mathrm{mg}$ $\mathrm{Hg}$ into the human body; the $\mathrm{LD}_{50}$ for $\mathrm{HgI}_{2}$ is at least two orders of magnitude greater) as it is from the hazard of employing a process using the materials. Mercuric iodide is quite volatile, $p=27$ torr at 500K. The iodate decomposes to the iodide on heating.

The vapor pressure of $\mathrm{TII}$ is appreciable, 0.6 torr at 700 and 355 torr at $1000 \mathrm{~K}$. The vapor pressure of $\mathrm{BiI}_{3}$ is quite high 0.36 torr at $500 \mathrm{~K}$ and 10 torr at $600 \mathrm{~K}$. It is less toxic, probably because it hydrolyzes readily; this fact in itself lessens its value as a fixation candidate. The iodates are more stable chemically than the iodides. However, the hydrolysis reaction may still be important.

For minimum iodine release under extreme conditions, the group II salts, $\mathrm{Ca}, \mathrm{Sr}$ and $\mathrm{Ba}$, appear to be the best choices of the iodates. In the absence of water, several other iodates would be acceptable. Silver iodide is the only iodide acceptable on the basis of thermal stability and resistance to air and water.

As has been noted, there is no stated basis for assuming that total isolation of ${ }^{129}$ I is the goal for iodine management. Thus there is no a priori basis for discarding a compound because, for example, of slow hydrolysis or oxidation. In fact, if dispersion of ${ }^{129}$ I with isotopic dilution is the accepted mode moderate instability is tolerable or even desirable, because, the "ideal" release rate is equal or less than the mixing rate. In view of this it is important to examine the availability and cost of many other compounds.

\section{Solid Sorbents}

The solid sorbents have been reviewed elsewhere (Jubin 1979; Holladay 1979; Burger and Burns 1979) and include various solids impregnated with silver or other metals, activated carbon, organic resins and zeolites. Those that have survived the efficiency tests of various laboratories and are compatible with process conditions, e.g., resistant to contaminant gases, are 
the high-silica zeolites and silver nitrate-impregnated amorphous silica. These two materials were tested further, the former in the form of silver exchanged Zeolon $900^{\circ}(\mathrm{AgZ})$, and the latter the Bayer product $A C-61200^{\circledR}$. Some comparative measurements were made on silver-exchanged faujasite, zeolite $X,(\mathrm{AgX})$. This material has a higher $\mathrm{Al}_{2} \mathrm{O}_{3} / \mathrm{SiO}_{2}$ ratio than mordenite and is much less acid-resistant. It does have a higher silver content and thus a higher iodine capacity. The silver zeolites were obtained from Ionex Corporation and the $A C-6120{ }^{\Theta}$ from United Catalysts, Inc. They were loaded with iodine by several techniques: 1) heating with measured amounts of $\mathrm{I}_{2}$ over periods of time up to $24 \mathrm{hr}$; 2) passing very dilute iodine through a bed of material for a 2-week period, and 3) loading-breakthrough experiments using either $\mathrm{I}_{2}$ or $\mathrm{CH}_{3} \mathrm{I}$. The temperature was normally $150^{\circ} \mathrm{C}$, but lower $\left(110^{\circ} \mathrm{C}\right)$ and higher $\left(240^{\circ} \mathrm{C}\right)$ values were also tried. Characterization studies employed thermal analysis, organic extraction and surface analysis.

The method or conditions of preparation, e.g., temperature, slow loading vs. rapid loading, made little difference in the product's stability. An exception was the water effect. The presence of water equivalent to about $10 \%$ or greater of the zeolite saturation value produced a more stable product. As measured by extraction with $\mathrm{CCl}_{4}$, this was more evident with type $\mathrm{X}$ zeolites $(\operatorname{Ag} X)$ than with the mordenite, and it appeared unimportant whether the water was introduced with the iodine or subsequent to it. Metal zeolites normally contain enough water to accommodate the reaction.

Depending on the extent of iodine loading, it was found possible to extract much of the iodine sorbed on AgX using carbon tetrachloride, tetrachlorethylene, toluene, and similar solvents by a Soxhlet technique. However, none was extracted from AgZ. Sorbed iodine produces a wide range of color--gray, green, brown, purple--but the color does not seem to relate directly to the ease of removal.

The iodine loading level is important because iodine is much more readily volatilized from higher loaded samples. The completely substituted mordenite contains about $1.67 \mathrm{mmol} \mathrm{Ag} / \mathrm{g}$, and $1: 1 \mathrm{I} / \mathrm{Ag}$ ratio corresponds to about $215 \mathrm{mg}$ I/g zeolite. Loadings used in this study were normally 50, 100, 150, and 200.

Zeolon $900^{\circ}$ is the registered trademark of the Norton Chemical Process Products Division of Norton Co., Akron, Ohio. 
Two types of thermal analysis were used. The first employed differential scanning calorimetry (DSC) or thermogravimetric analysis (TGA) to examine the prepared samples. In the second the DSC apparatus was used to study the loading reaction. The studies show that the iodine sorbed on AgZ up to about $45 \mathrm{mg} / \mathrm{g} \mathrm{AgZ}$ is firmly bound, probably largely as AgI, and is not released by heating. Iodine in excess of this is released between 250 and $500^{\circ} \mathrm{C}$ and is apparently held in a moderately stable complex involving silver. A practical loading for AgZ in a trapping system is about $140 \mathrm{mg} / \mathrm{g}$ (Thomas et al. 1977); thus much of the sorbed iodine is not firmly fixed. Iodine-loaded $\mathrm{Ag}^{\circ} \mathrm{Z}$ and AgX behaved similarly. Lead exchanged zeolite $X, P b X$, loaded with iodine from a dilute $\mathrm{HI}$ gas stream, was found to release iodine beginning at $150^{\circ} \mathrm{C}$. The iodine containing $A C-6120$ contains silver nitrate making the thermal analysis more involved, but iodine does appear to be more firmly fixed.

Thermal transitions characteristic of AgI are seen in some samples. One would not expect to see transitions characteristic of massive crystalline compounds in the isolated groups of molecules in the zeolite cavities; and, indeed, we have not observed them in other laboratory preparations.

Brief examinations of these materials using surface analysis techniques, Auger and ESCA, indicated that the bonding of iodine to silver was different in AgZI than in AgI. Scanning electron microscopy coupled with $X$-ray fluorescence analysis showed that at a loading of $150 \mathrm{mgI} / \mathrm{g}$ AgZ the iodine was uniformly distributed. After reduction of $\mathrm{AgZ}$ to $\mathrm{Ag}^{\circ} \mathrm{Z}$, iodine distribution is no longer even because of silver migration. This is discussed further by Scheele (1980c; 1981c).

\section{Alternative Forms}

As mentioned earlier, glasses have been considered by French workers. Glasses based on fluoride--likely to be compatible with iodine compounds--tend to be rather soluble in water. No actual data have been found.

Synthetic minerals are an attractive possibility, and one of the best may be sodalite. This has been studied by Winters and Johnston for the Pacific Northwest Laboratory (Winters 1980). 
Iodide sodalite is easily prepared by reacting $\mathrm{NaI}, \mathrm{NaOH}$, and kaolinite clay in stoichiometric amounts at low temperature in an aqueous slurry. Complete incorporation of the iodine into the sodalite aluminosilicate lattice and densification of the product are accomplished by hot-pressing at $1000^{\circ} \mathrm{C}$ and $34.5 \mathrm{MPa}$ (5000 psi) for $1 \mathrm{hr}$, after a $1 \mathrm{hr}$ heat-up at the same pressure. The final product is a very hard, mechanically stable material, with a density of $2.4 \mathrm{~g} / \mathrm{cm}^{3}$ (theoretical density $=2.6 \mathrm{~g} / \mathrm{cm}^{3}$ ). The hot-pressed sodalites have near-theoretical iodine contents of $\sim 19$ wt\% (maximum loading = 22 wt\%). Good thermal and radiation stabilities have been reported (Vance et al. 1981). Leach rates of some samples have been very $10 \mathrm{w}, \sim 10^{-6} \mathrm{~g} / \mathrm{cm}^{2}-d$, corresponding to about $6 \times 10^{-6} \mathrm{~cm} / \mathrm{d}$ normalized rate. Iodine losses observed during the entire process amount to only a few percent, occurring during the hot pressing. In a properly designed system, these losses should be recoverable for recycle into the feed stream. 


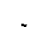

- 
Cost and availability data for the candidate fixation materials are listed in Table 8 . Costs ranged from $\langle \$ 0.40 / \mathrm{kg}$ to $>\$ 4000 / \mathrm{kg}$. The cation cost from least to most expensive was $\mathrm{Ca}<\mathrm{Sr}, \mathrm{Ba}, \mathrm{Zn}, \mathrm{Pb}, \mathrm{Cu}<\mathrm{Ce}, \mathrm{Bi}, \mathrm{Ni}, \mathrm{Tl}, \mathrm{Hg}$ $<\mathrm{Ag}<\mathrm{Pd}$. Based on similarity in cost trends between most of the compounds and metals (Wiemers 1978a), La and U would be comparable with the Ce group. In terms of U.S. primary production/demand, $\mathrm{Ca}, \mathrm{La}, \mathrm{Tl}$, and $\mathrm{Ce}$ were all acceptable. $\mathrm{Cu}, \mathrm{Pb}, \mathrm{Ba}$, and $\mathrm{Ni}$ were borderline cases. $\mathrm{Sr}, \mathrm{Pd}, \mathrm{Ag}$, and $\mathrm{Zn}$ were least acceptable. World reserve and resource were satisfactory for all but $\mathrm{Bi}$, and possibly for $\mathrm{Ag}$ and $\mathrm{Hg}$. On the basis of cost and availability $\mathrm{Ag}$, $\mathrm{Pd}$, and $\mathrm{Bi}$ are the least desirable. Of the candidate fixation materials remaining in Tables 1 and 2, $\mathrm{Ca}$ and $\mathrm{Ba}$ followed by $\mathrm{Ni}, \mathrm{Ce}$, and $\mathrm{La}$ are recommended for the iodates, and $\mathrm{Ph}, \mathrm{Cu}$ and possibly $\mathrm{Ni}$ are recommended for the iodides based only on a cost and availability analysis. 
IABLE 8. Cost and Availability Data for Candidate Iodine Fixation Materials

\begin{tabular}{|c|c|c|c|c|c|}
\hline Metal & Compound & $\begin{array}{c}\text { Cost }^{(a)} \\
\$ / \mathrm{kg} \text { Cation }\end{array}$ & $\begin{array}{l}\text { U.S. Primary } \\
\text { Production } \\
\text { to Demand }(c) \\
\end{array}$ & $\begin{array}{l}\text { Availability } \\
\text { World Reserve } \\
\text { to Demand }(\mathrm{d}, \mathrm{e}) \\
\end{array}$ & $\begin{array}{l}\text { World Resource } \\
\text { to Demand }(\mathrm{d}, \mathrm{e})\end{array}$ \\
\hline $\mathrm{Ag}$ & & & 0.22 & 0.44 & 1.7 \\
\hline & $\mathrm{AgNO}_{3}$ & 304 & & & \\
\hline $\mathrm{Ba}$ & & & 0.69 & 0.84 & 8.4 \\
\hline & $\mathrm{BaO}$ & 0.77 & & & \\
\hline & $\mathrm{Ba}(\mathrm{OH})_{2}{ }^{\circ} \mathrm{H}_{2} \mathrm{O}$ & 1.67 & & & \\
\hline & $\mathrm{Ba}(\mathrm{OH})_{2} \cdot \mathrm{BH}_{2} \mathrm{O}$ & 2.07 & & & \\
\hline$B i$ & & 5.51 & 0.36 & 0.49 & 1.1 \\
\hline & $\mathrm{Bi}_{2} \mathrm{O}_{5}$ & 52.9 & & & \\
\hline $\mathrm{Ca}$ & & & 1.02 & (h) & (h) \\
\hline & $\mathrm{CaCl}_{2}$ & 0.37 & & & \\
\hline & $\mathrm{CaSO}_{4}$ & 0.13 & & & \\
\hline $\mathrm{Ce}$ & & & 1.77 & 4.5 & 22 \\
\hline & $\mathrm{CeO}_{2}{ }^{\circ} \times \mathrm{H}_{2} \mathrm{O}$ & 5.56 & & & \\
\hline Cu & & & 0.69 & 0.84 & 8.4 \\
\hline & $\mathrm{Cu}\left(\mathrm{NO}_{3}\right)_{2}$ & 2.78 & & & \\
\hline & $\mathrm{CuSO}_{4} \cdot \mathrm{SH}_{2} \mathrm{O}$ & 3.97 & & & \\
\hline $\mathrm{Pb}$ & & & 0.63 & 1.25 & 2.4 \\
\hline & $\mathrm{Pb}\left(\mathrm{NO}_{3}\right)_{2}$ & 1.12 & & & \\
\hline & $\mathrm{PbCl}_{2}$ & 9.61 & & & \\
\hline & $\mathrm{PbSO}_{4} \cdot \mathrm{PbO}$ & 2.25 & & & \\
\hline La & (b) & & 1.77 & 4.5 & 22 \\
\hline $\mathrm{Hg}$ & & & 0.53 & 0.75 & 2.7 \\
\hline & $\mathrm{HgO}$ & 31.97 & & & \\
\hline & $\mathrm{Hg}_{2} \mathrm{Cl}_{2}$ & 15.98 & & & \\
\hline $\mathrm{Ni}$ & & & 0.70 & 2.1 & 4.2 \\
\hline & $\mathrm{Ni}\left(\mathrm{NO}_{3}\right)_{2}$ & 6.22 & & & \\
\hline & $\mathrm{NiSO}_{4}$ & 6.00 & & & \\
\hline $\mathrm{Pd}$ & & 4938 & 0.016 & 2.4 & 6.9 \\
\hline
\end{tabular}


Table 8 (continued)

\begin{tabular}{|c|c|c|c|c|c|}
\hline Metal & Compound & $\begin{array}{c}\text { Cost }^{(a)} \\
\$ / \mathrm{kg} \text { Cation }\end{array}$ & $\begin{array}{l}\text { U.S. Primary } \\
\text { Production } \\
\text { to Demand (c) }\end{array}$ & $\begin{array}{l}\text { Availability (b) } \\
\text { World Reserve } \\
\text { to Demand }(d, e)\end{array}$ & $\begin{array}{l}\text { World Resource } \\
\text { to Demand }(d, e)\end{array}$ \\
\hline \multirow[t]{3}{*}{$\mathrm{Sr}$} & & & 0 & 2.0 & "adequate" \\
\hline & $\mathrm{SrCO}_{3}$ & 1.04 & & & \\
\hline & $\mathrm{Sr}\left(\mathrm{NO}_{3}\right)_{2}$ & 1.28 & & & \\
\hline $\mathrm{Tl}$ & & & 2.14 & 1.2 & (h) \\
\hline & $\mathrm{Tl}_{2} \mathrm{SO}_{4}$ & 13.76 & & & \\
\hline $\operatorname{Th}^{(i)}$ & & & 3.8 & 110 & (h) \\
\hline$u^{(i)}$ & $(f, g)$ & & 0.27 & 0.41 & 0.71 \\
\hline \multirow[t]{4}{*}{ Zn } & & & 0.36 & 1.1 & 6.9 \\
\hline & $\mathrm{ZnCl}_{2}$ & 0.60 & & & \\
\hline & $\mathrm{Zn}\left(\mathrm{NO}_{3}\right)_{2}$ & 2.18 & & & \\
\hline & $\mathrm{ZnSO}_{4}$ & 1.43 & & & \\
\hline
\end{tabular}

a. All cost values are from Chemical Marketing Reporter (1981).

b. All availability values are from Bureau of Mines except for Ca. The values for Ca represent the quantity of $\mathrm{CaCl}_{2}$ traded in 1972 as given by Bureau of Mines (1975). Ce and La values are for the total quantity of rare-earth oxide. Ce and La comprise $80 \%$ of this group.

c. Ratio is given for U.S. Primary Production predicted for year 2000 versus U.S. Demand predicted for year 2000.

d. Ratio of World Reserve or Resource estimated in the year 1974 versus predicted Demand for year 1974-2000.

e. Identified resources are specific bodies of mineral-bearing material whose location, quality, and quantity are known from geologic evidence supported by engineering measurements regarding the demonstrated category, and includes reserves and subeconomic resources. The reserve is that portion of the identified resource from which available mineral or energy commodity can be economically and legally extracted at the time of determination.

f. No price quotes listed in Chemical Marketing Reporter (1981).

g. The values for domestic demand and production and world demand are for uranium to be used for enrichment. The estimated domestic demand for depleted uranium in the year 2000 was $3.99 \times 10^{3}$ $t ; 6 \%$ of the total domestic demand. About $97 \%$ of the demand for uranium to be used for enrichment will be added to the depleted uranium stockpiles providing an abundance of depleted uranium relative to its demand. Reserve and resource values are determined for natural uranium.

h. Information not available.

i. Th and $U$ were originally included because of the properties of the iodates. They can probably be eliminated because of associated radioactivity and the potential hydrolysis reactions. 


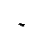




\section{LEACH RESISTANCE}

Contact of the ${ }^{129}$ I disposal form with water may occur either by design or by accident. For the dispersal strategy, removal of iodine by leaching is part of the design. On the other hand, if an isolation strategy is assumed the possibility of aqueous contact must also be considered. In either case the goal is to assure a low concentration and/or a high isotopic dilution with 127 I. Both are easily achieved with ocean disposal and the leach rate is not critical. For isolation, e.g., storage in granitic or argillaceous deposits or in salt caverns, the leaching rate becomes very important. Thus a wide range of leach rates may be of interest.

\section{PAST WORK}

W. E. Clark (1977), M. T. Morgan et al. (1978), J. A. Partridge and G. P. Bosuego (1979) and the Pacific Northwest Laboratory have performed leaching studies on selected iodine compounds in cement, evaluating various cement additives or coatings.

Clark used a modified IAEA dynamic leach simulation test to evaluate $\mathrm{Ba}\left(\mathrm{IO}_{3}\right)_{2}, \mathrm{AgIO}_{3}, \mathrm{Hg}\left(\mathrm{IO}_{3}\right)_{2}$, and $\mathrm{Pb}\left(\mathrm{IO}_{3}\right)_{2}$ in portland I cement as disposal forms for ${ }^{129}$ I captured using the Iodox process. Of the iodates tested, $\mathrm{Ba}\left(\mathrm{IO}_{3}\right)_{2}$ in cement was generally superior and the most consistent; he did find some samples of $\mathrm{Hg}\left(\mathrm{IO}_{3}\right)_{2}$ and $\mathrm{AgIO}_{3}$ in cement to perform comparably. He reported that a cylinder $2.54 \mathrm{~cm}$ diam and $2.54 \mathrm{~cm}$ high had a leach rate of $3 \times 10^{-4}$ $\mathrm{cm} / \mathrm{d}(\mathrm{a})$ between days 30 and 60 . Of the coatings and additives tried, buty 1 stearate additive proved the most effective and reduced the leach rate by a factor of 3 .

Morgan and coworkers evaluated the effect of water, cement ratios, curing time, iodine content, gamma irradiation, and different leachate compositions on iodine leaching from $9-15$ wt\% $\mathrm{Ba}\left(\mathrm{IO}_{3}\right)_{2}$ cement using a modified IAEA leach test. Their studies showed that only the leachate composition caused a significant change in leach rates. Their estimated effective diffusion

(a) The leach rate unit of $\mathrm{cm} / \mathrm{d}$ may be converted to fraction leached per day by multiplying by the surface to volume ratio. 
coefficient in distilled water was $D_{e}=1.9 \times 10^{-4} \exp (-4163 / T, \mathrm{~K}) \mathrm{cm}^{2} / \mathrm{sec}$. The values of $D_{e}$ in seawater, simulated seawater, tap water, and spring water were $10^{4}$ times lower than in distilled water. This reduction was attributed to the formation of a protective surface film which slowed iodine loss.

Partridge and Bosuego studied the leaching of 26.9 wt\% mercuric iodate in cement. The mercuric iodate was produced by their process that uses nitric acid to oxidize iodine in mercurex solution. In addition to their test using pure mercuric iodate, another test using 2.9 wt\% mercuric iodate and 24.8 wt\% mercuric nitrate was performed. They used a simulated dynamic leach procedure in both cases. The former had a greater leach rate $6.72 \times 10^{-3} \mathrm{~cm} / \mathrm{d}$ compared to $3.56 \times 10^{-3} \mathrm{~cm} / \mathrm{d}$ between days 1 and 10 .

Preliminary studies at PNL (Wiemers 1978b, 1978c, 1979a, 1979b, 1979c), consisted of three screening tests to evaluate the effects of leaching method, environmental parameters, cement additives and coatings, and the nature of the iodine compound on iodine leachability from portland type III cement. Summarizing the most signficant factors in these tests: (1) for pure iodine compounds in cement, approach to dynamic leach conditions increased leach rates, (2) higher temperature increased leach rates, (3) high carbonate leachate concentration decreased leach rates, (4) iodine loading in cement of $>5$ wt\% increased leach rates, and (5) low iodine compound solubility decreased leach rates. No additives or coatings tested had a significant effect.

\section{PRESENT WORK}

From the data accumulated on solubilities, thermal stabilities, cost and availability, toxicity, leach characteristics from earlier screening studies, and likely end products of the various iodine capture processes described earlier, several iodides, iodates, and iodine-containing solid sorbents fixed in cement were selected for further leaching studies. The iodine forms chosen were $\mathrm{CuI}, \mathrm{PbI} 2, \mathrm{AgI}, \mathrm{Ba}\left(\mathrm{IO}_{3}\right)_{2}, \mathrm{~Pb}\left(\mathrm{IO}_{3}\right)_{2}, \mathrm{Hg}\left(\mathrm{IO}_{3}\right)_{2}, 150 \mathrm{mgI} / \mathrm{g}$ silver mordenite $(A g Z I)$, and HI-loaded (370 mgI/g) lead zeolite $X(P b X I)$.

\section{Experimental}

Characteristics of a typical iodine-containing cement monolith are listed in Table 9. The monoliths were suspended in glass beakers containing the leachate at ambient temperature $\left(19-23^{\circ} \mathrm{C}\right)$, and the tests were performed in 
air. The leachate-to-surface-area ratio was 10:1. The results are presented as the normalized fraction leached, which is calculated by multiplying the fraction leached by the sample's geometric volume-to-surface area ratio. This value was normally $0.5 \mathrm{~cm}$.

TABLE 9 - Typical Characteristics of Iodine-Cement Monoliths

\begin{tabular}{lcc}
\multicolumn{1}{c}{ Property } & Value \\
\cline { 1 - 2 } Iodine concentration, mmol I/g dry cement & 0.8 \\
Cement type & Portland Type III \\
Water/cement weight ratio & 0.3 \\
Height, cm & 4.5 \\
Diameter, cm & 2.54 \\
Geometric volume, V, $\mathrm{cm}^{3}$ & 23.0 \\
Geometric surface area, S, $\mathrm{cm}^{2}$ & 45.0 \\
V/S, cm & 0.5 \\
Curing time & 7 days
\end{tabular}

Two leach test procedures were used: a modified IAEA dynamic leach test and a static leach test. In the modified IAEA test the leachate was gently agitated on a mechanical shaker and was changed at selected intervals. A typical sampling schedule was three times daily for the first week, twice per day for week 2, once per day for weeks 3 through 5 , and once per week through week 9. The leachate was distilled water. The iodine forms tested by the modified IAEA method were $\mathrm{AgI}, \mathrm{Ba}\left(\mathrm{IO}_{3}\right)_{2}, \mathrm{Ca}\left(\mathrm{IO}_{3}\right)_{2}$, and $\mathrm{AgZI}$, all in portland type III cement. In the static leach test, we typically sampled the leachate on days $3,7,14,56,112$, and 180 and replaced the sample with an equal volume of leachate preequilibrated with a pure cement sample. The iodine forms tested by the static method were $\mathrm{AgI}, \mathrm{CuI}, \mathrm{PbI}, \mathrm{Ba}\left(\mathrm{IO}_{3}\right)_{2}, \mathrm{Ca}\left(\mathrm{IO}_{3}\right)_{2}$, $\mathrm{Hg}\left(\mathrm{IO}_{3}\right)_{2}$, PbXI, and AgZI all in portland type III cement. Distilled water was the leachate. For $\mathrm{Ba}\left(\mathrm{IO}_{3}\right)_{2}$ and $\mathrm{Hg}\left(\mathrm{IO}_{3}\right)_{2}$ seawater and Columbia River water leachates were also tested.

An iodide-specific ion electrode was used for the leachate analysis. For iodates, reduction was first carried out using hydroxylamine. The detection limit was $\sim 10^{-7} \underline{\mathrm{M} \mathrm{I}} \mathrm{I}^{-}$. 
Results

Iodides

$\mathrm{CuI}$ and $\mathrm{PbI}_{2}$ have low solubilities but are susceptible to oxidation and to hydrolysis in the alkaline environment of the cement, $\mathrm{pH} \sim 12$. There are no cations in the cement capable of lowering the solubility of the iodine released. In leach tests, $\mathrm{CuI}$ and $\mathrm{PbI}_{2}$ lost iodine very rapidly, e.g., for CuI $20 \%$ in 15 days.

$\mathrm{AgI}$ has a very low solubility and thus good leach resistance. Figures 1 and 2 present the results for the static and the dynamic leach tests of AgI in cement, respectively. Using the data presented in Figure 2 for the dynamic simulation test between days 40 and 100 , the leach rate was $8 \times 10^{-7} \mathrm{~cm} / \mathrm{d}$. At this rate it would take 430 years to 1 each $1 \%$ of the iodine from a $208-\mathrm{L}$ cement monolith.

For the iodides, AgI in cement was the best disposal form tested, and even though it is expensive (see Table 8 ), it is the recommended form for an iodide product.

\section{Iodates}

Iodates are typically more soluble than iodides but are resistant to oxidation. Unfortunately, hydrolysis still can occur. Also, it must be noted that much of the earth's crust is reducing, e.g., containing $\mathrm{Fe}^{+2}$ ion, and slow reduction of iodates is a possibility especially at low pH. The group II iodates are quite insoluble (Table 2) when contrasted with the corresponding hydroxides. Thus the iodates of $\mathrm{Ca}, \mathrm{Sr}$, and $\mathrm{Ba}$ are potential candidates. These as well as $\mathrm{Hg}\left(\mathrm{IO}_{3}\right)_{2}$ and $\mathrm{Pb}\left(\mathrm{IO}_{3}\right)_{2}$ have been examined in cement. Unfortunately, in the case of lead, attempts to prepare physically stable cement met with failure. Results from the static leach tests for $\mathrm{Ba}, \mathrm{Hg}$ and Ca are shown in Figures 3, 4, and 5. Little difference is seen between these forms. The normalized fraction leached for each is $\sim 3 \times 10^{-3} \mathrm{~cm}$ after 90 days. The normalized fraction leached in the dynamic tests for $\mathrm{Ba}\left(\mathrm{IO}_{3}\right)_{2}$, $\mathrm{Ca}\left(\mathrm{IO}_{3}\right)_{2}$, and in the earlier study for $\mathrm{Sr}\left(\mathrm{IO}_{3}\right)_{2}$ are similar. Figure 6 shows the dynamic leach results for $\mathrm{Ba}\left(\mathrm{IO}_{3}\right)_{2}$. Note that the fraction leached dynamically is a factor of 10 greater than in the static test. 


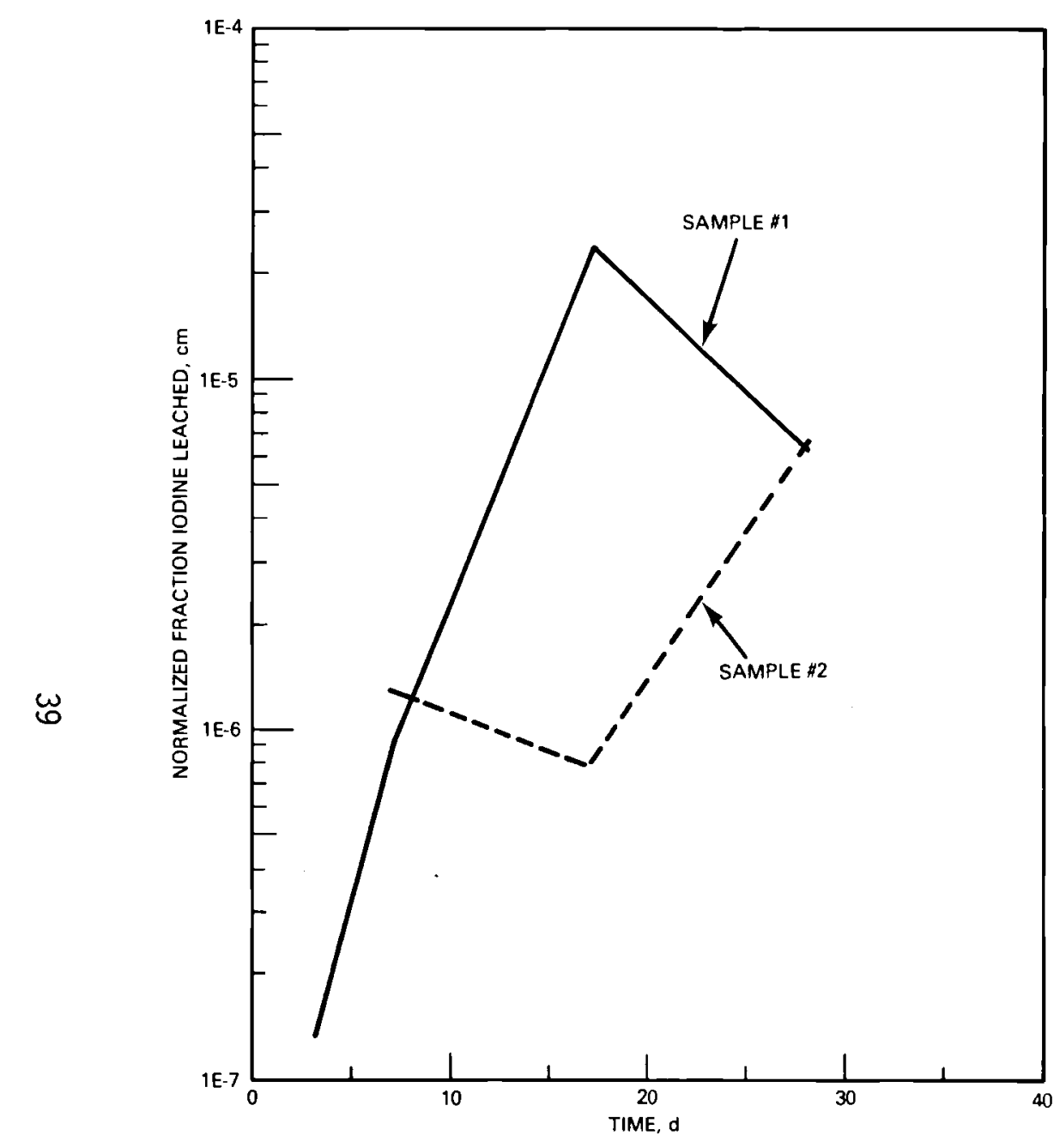

FIGURE 1. Static Leach Test of AgI in Portland Type III Cement, $0.8 \mathrm{mmol} \mathrm{AgI} / \mathrm{g}$ Dry Cement (Distilled Water Leachate)

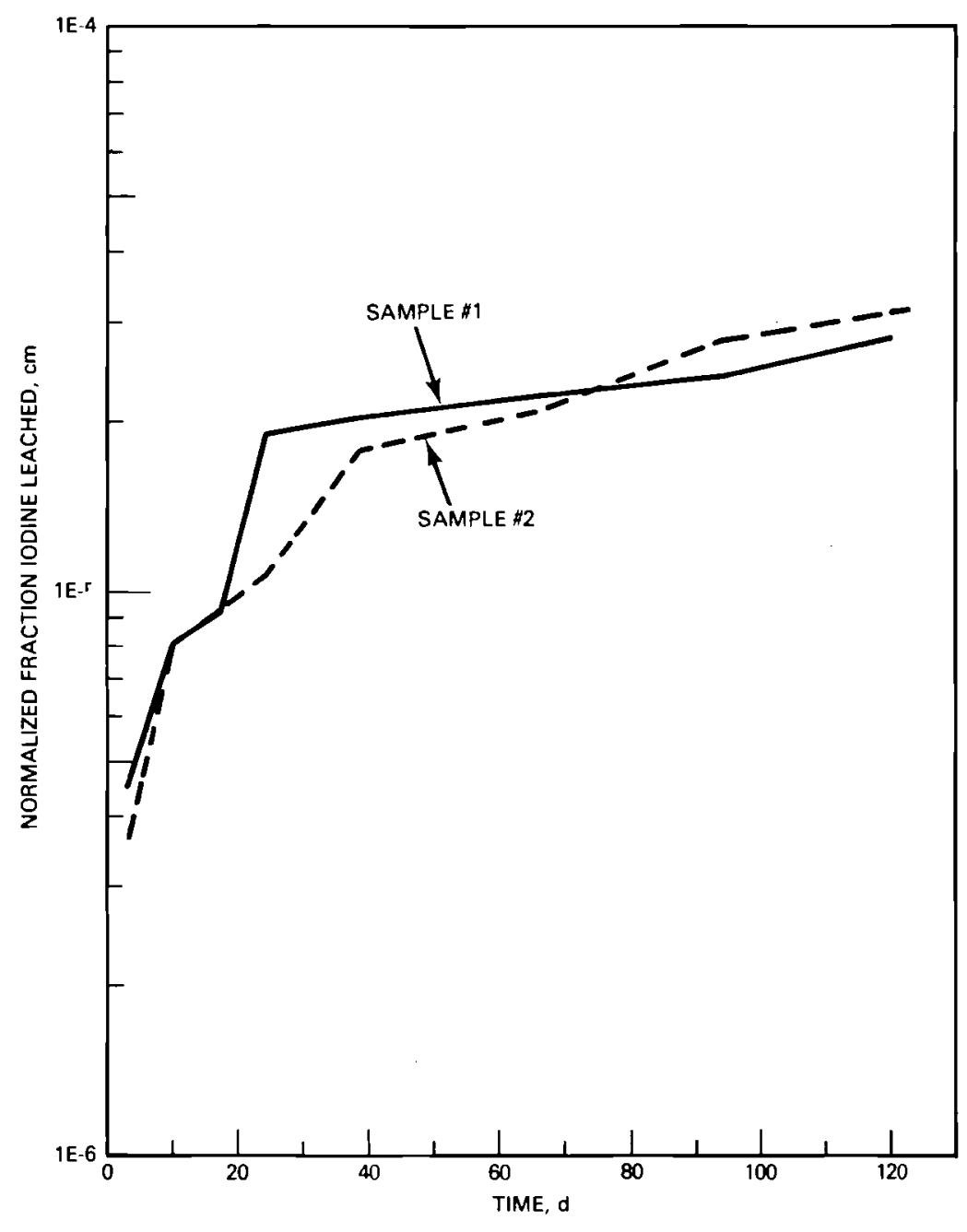

FIGURE 2. Simulated Dynamic Leach Test of AgI in Portland Type II I Cement, 0.8 mmol $\mathrm{AgI} / \mathrm{g}$ Dry Cement (Cement-Equilibrated Distilled Water Leachate) 


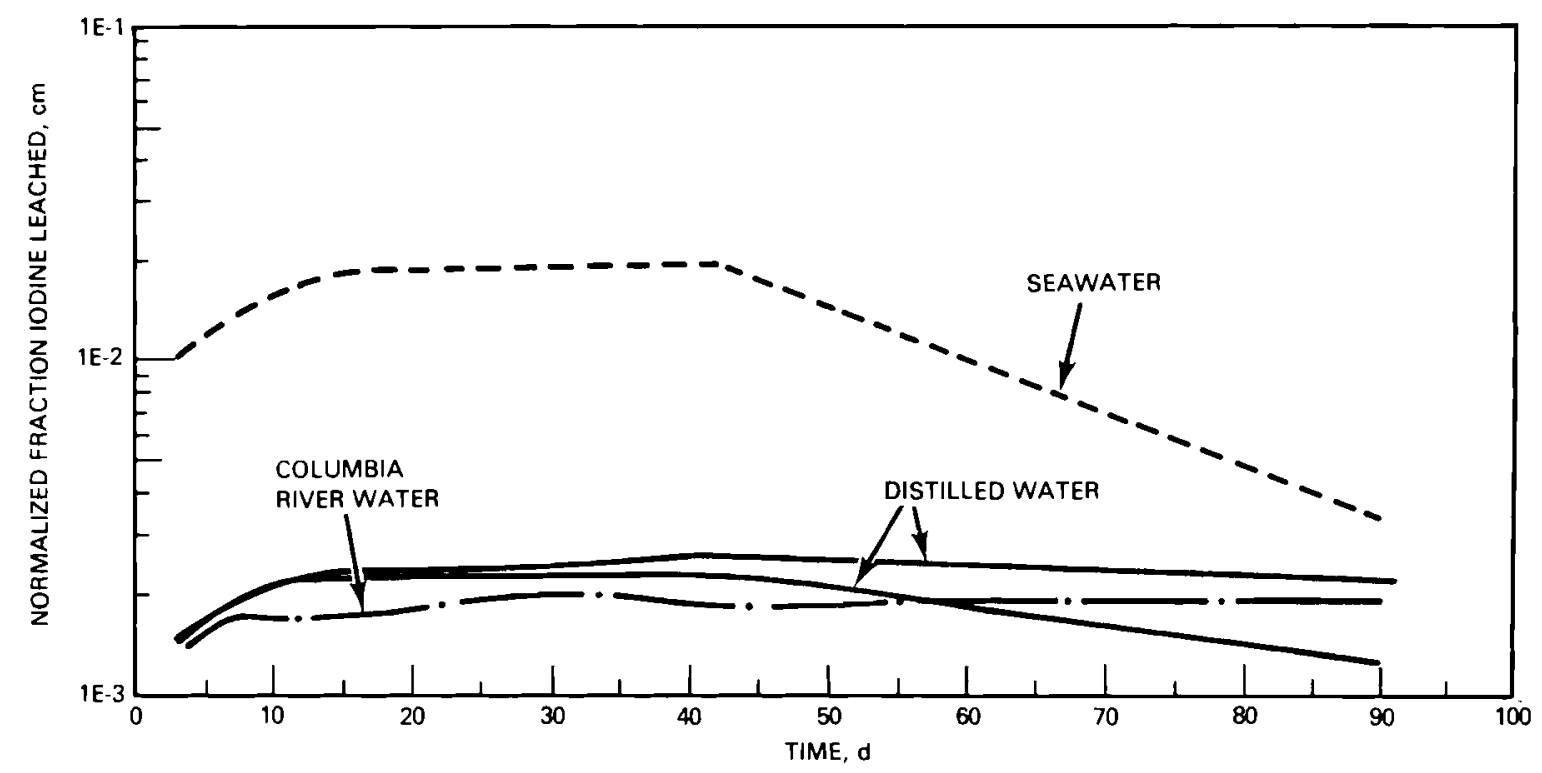

FIGURE 3. Static Leach Test of $\mathrm{Ba}\left(\mathrm{IO}_{3}\right)_{2}$ in Portland Type III Cement, 0.4 mmol $\mathrm{Ba}\left(\mathrm{IO}_{3}\right)_{2} / \mathrm{g}$ Dry Cement

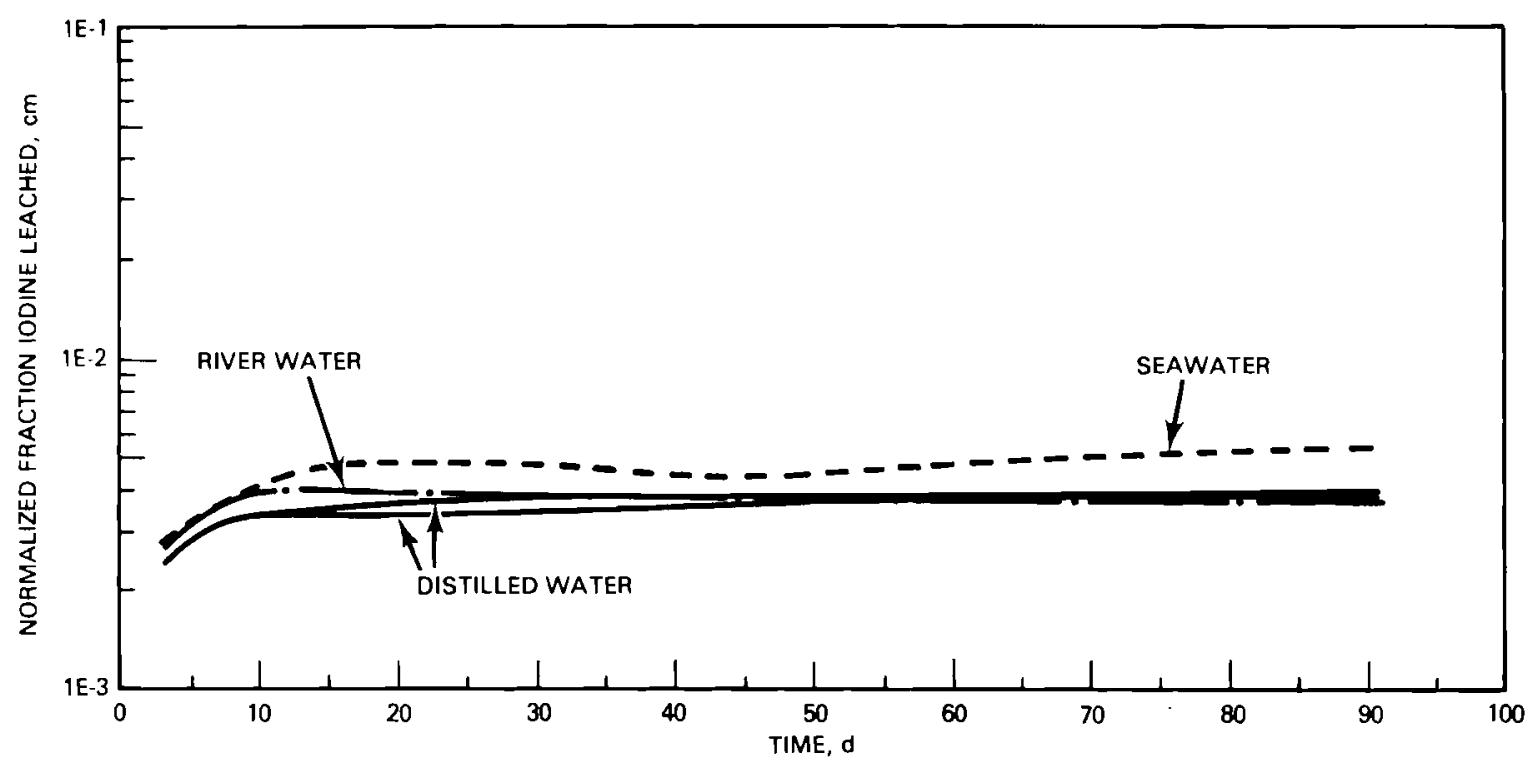

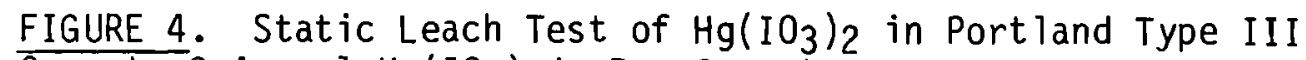
Cement, $0.4 \mathrm{mmol} \mathrm{Hg}\left(\mathrm{IO}_{3}\right) 2 / \mathrm{g}$ Dry Cement 


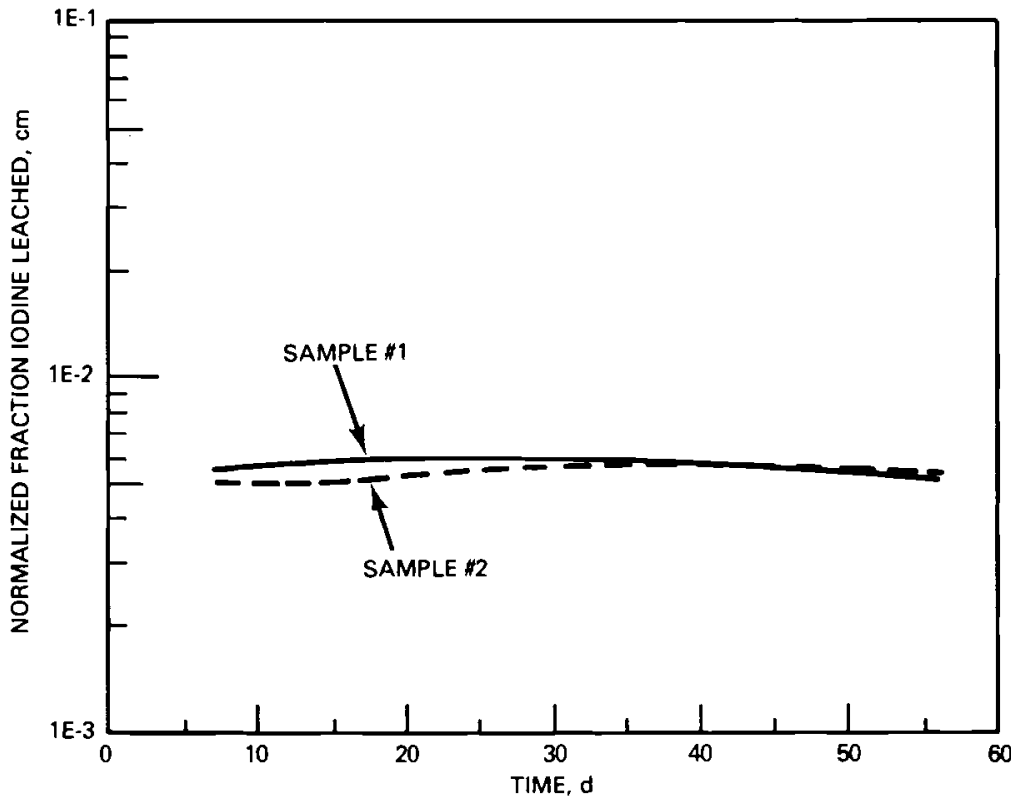

FIGURE 5. Static Leach Test of $\mathrm{Ca}\left(\mathrm{IO}_{3}\right)_{2}$ in Portland Type III Cement, $0.4 \mathrm{mmol}$ $\mathrm{Ca}\left(\mathrm{IO}_{3}\right)_{2} / \mathrm{g}$ Dry Cement (Distilled Water Leachate)

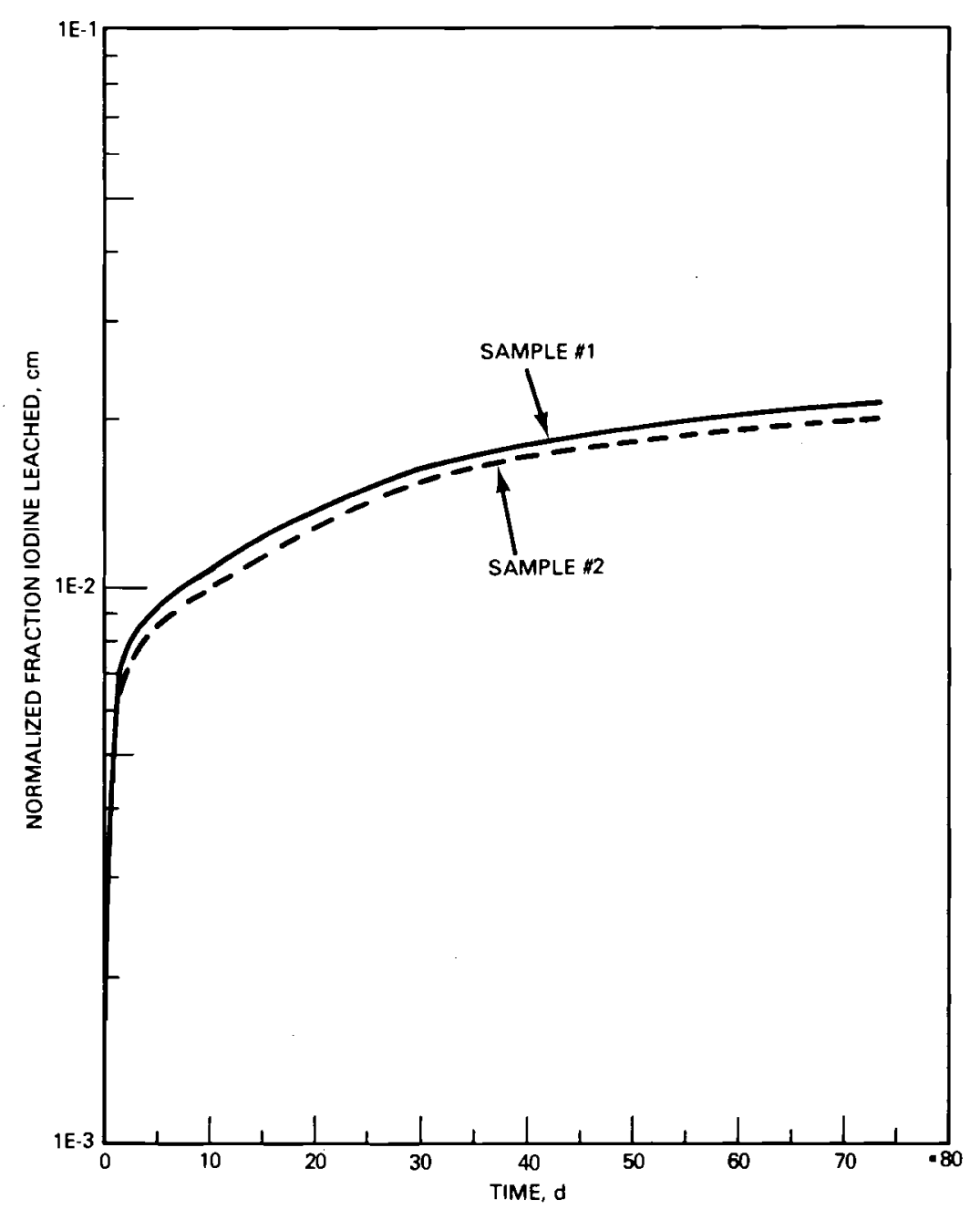

FIGURE 6. Simulated Dynamic Leach Test of $\mathrm{Ba}\left(\mathrm{IO}_{3}\right)_{2}$ in Port land Type III Cement $0.4 \mathrm{mmol} \mathrm{Ba}\left(\mathrm{IO}_{3}\right)_{2} / \mathrm{g}$ Dry Cement (Distilled Water Leachate) 
Using the dynamic test results for $\mathrm{Ba}\left(\mathrm{IO}_{3}\right)_{2}$ between days 40 and 70 , the leach rate is estimated at $7 \times 10^{-5} \mathrm{~cm} / \mathrm{d}$, which is comparable to that obtained by Clark (1979). This rate corresponds to a $1 \%$ loss from a $208 \mathrm{~L}$ monolith in 5 years.

Unfortunately, it is difficult to compare our static leach test results for $\mathrm{Hg}\left(\mathrm{IO}_{3}\right)_{2}$ in cement to the simulated dynamic tests of Partridge and Bosuego (1979). If, however, the factor of 10 difference seen in our own tests between static and simulated dynamic tests holds, our results appear comparable to Partridge and Bosuego's, especially taking their higher iodine content into account.

Solid Sorbents

The solid sorbents considered are potential disposal forms as used. However, granular or powder forms present handling problems in addition to much lower resistance to leaching or volatilization. We believe immobilization in a monolithic form is desirable.

As mentioned in the discussion on iodine capture technologies, silver zeolites $(A g Z, A g X)$, and $\mathrm{PbX}$ have been considered for capture and storage of ${ }^{129}$ I. Both iodine-loaded $\mathrm{AgZ}$ (150 mgI/gAgZ), AgZI and hydrogen iodide-loaded $\mathrm{PbX}(370 \mathrm{mg} \mathrm{I} / \mathrm{g} \mathrm{PbX}$ ), PbXI have been leach-tested. The AgZI cement samples contained $0.8 \mathrm{mmol} \mathrm{I} /(\mathrm{g}$ dry cement $+\mathrm{AgZ})$, and the PbXI cement samples contained $\sim 1 \mathrm{mmol} \mathrm{I} /(\mathrm{g}$ dry cement $+\mathrm{PbX})$. The results for the static tests are presented in Figures 7 and 8 .

When PbXI was added to the cement, the cement mixture turned purple, suggesting release of elemental iodine. Figure 7 shows that the iodine is easily leached from this material.

Comparison of the dynamic leach rates for AgZI in cement (Figure 9) with the dynamic leach rates for $\mathrm{Ba}\left(\mathrm{IO}_{3}\right)_{2}$ in cement (Figure 6) shows that iodine is is leached from the AgZI cement an order of magnitude slower than from the $\mathrm{Ba}\left(\mathrm{IO}_{3}\right)_{2}$ cement; in the static tests the rates were roughly equivalent. In the dynamic test the iodine leached a factor of 10 faster than from pure AgI in cement. This is to be expected since our studies have shown that only a portion of the iodine sorbed on AgZ is AgI. Based on Sample 1 in Figure 9, at a leach rate of $4 \times 10^{-6} \mathrm{~cm} / \mathrm{d}$ it would take $100 \mathrm{yr}$ to leach $1 \%$ of the iodine from a 208-L cement monolith. 

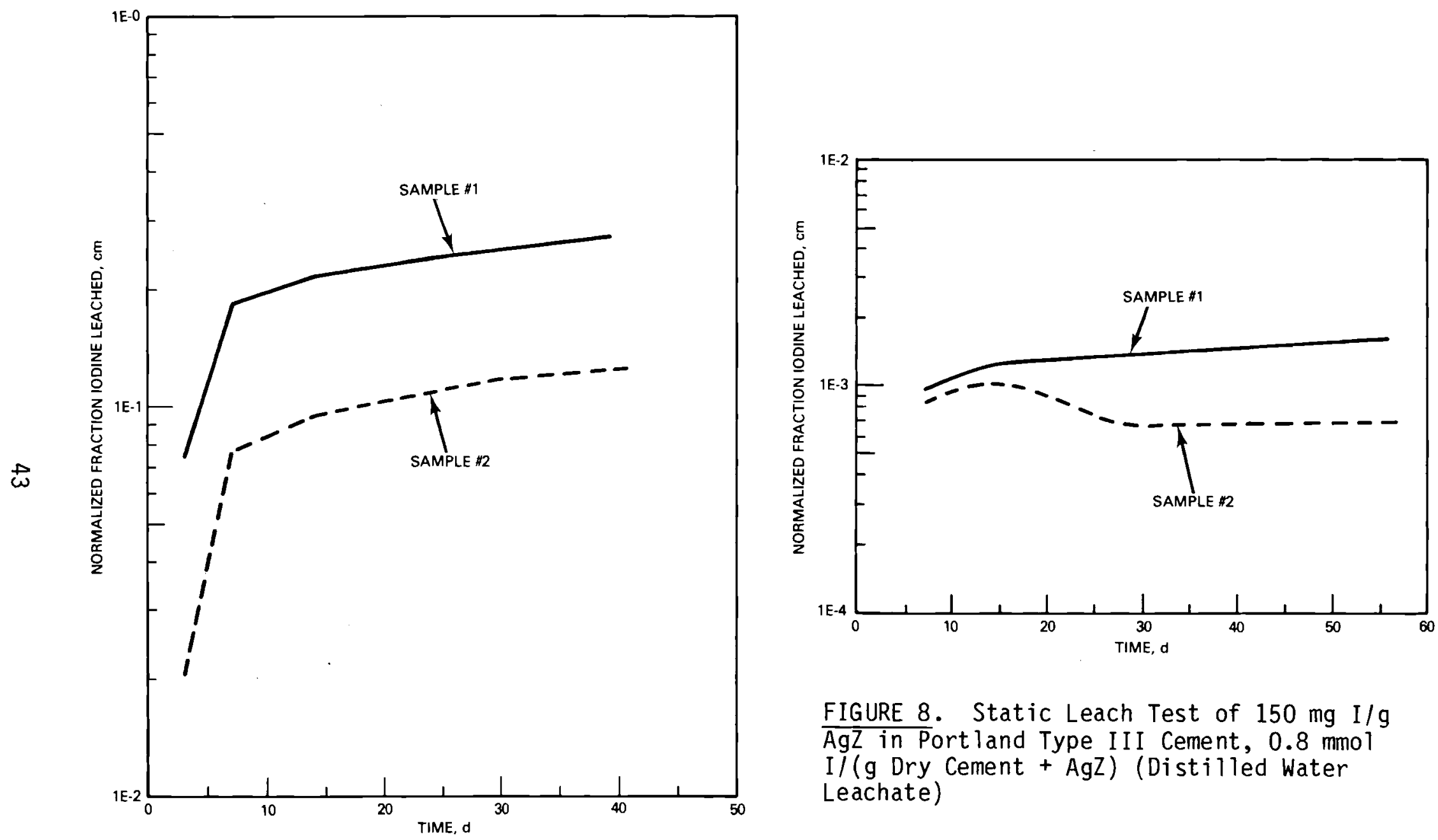

FIGURE 8. Static Leach Test of $150 \mathrm{mg} \mathrm{I} / \mathrm{g}$ AgZ in Port land Type II I Cement, $0.8 \mathrm{mmol}$ I/ (g Dry Cement + AgZ) (Distilled Water Leachate)

FIGURE 7. Static Leach Test of $\sim 370 \mathrm{mg} \mathrm{I} / \mathrm{g}$ PbX in Portland Type II I Cement, 1 mmol I/ (g Dry Cement $+\mathrm{PbX})$ (Distilled Water Leachate) 
Comparison of Figure 9 with Figure 8 shows equivalent leaching for the dynamic and static leach tests for AgZI in cement. Tests on AgZI in cement have given mixed results.

Our studies have shown PbXI in cement to be a poor selection for a disposal form for ${ }^{129}$ I, while AgZI in cement is adequate, especially if the isotopic dilution disposal strategy is selected. AgZI in cement is not as good as AgI in cement. The behavior of the former is expected to be dependent on the iodine loading since, as described above, only $40-50 \mathrm{mg} / \mathrm{g}$ load as $\mathrm{AgI}$. Furthermore, the use of silver would be more efficient if $\mathrm{AgI}$ is used instead of AgZI.

\section{Alternative Forms}

In addition to our leaching studies on iodine compounds in cement, we used the static leach procedure to test an iodine sodalite prepared by $W$. I. Winters of Rockwell Hanford Operations. The results for distilled water are presented in Figure 10. The static leaching results were a factor of 100 improved compared to $\mathrm{Ba}\left(\mathrm{IO}_{3}\right)_{2}$ in cement and were equivalent to $\mathrm{AgI}$ in cement.

This sodalite was comparable to the best pure iodine compound in cement tested. With additional protection such as incorporation into cement, the leach resistance should be improved. 


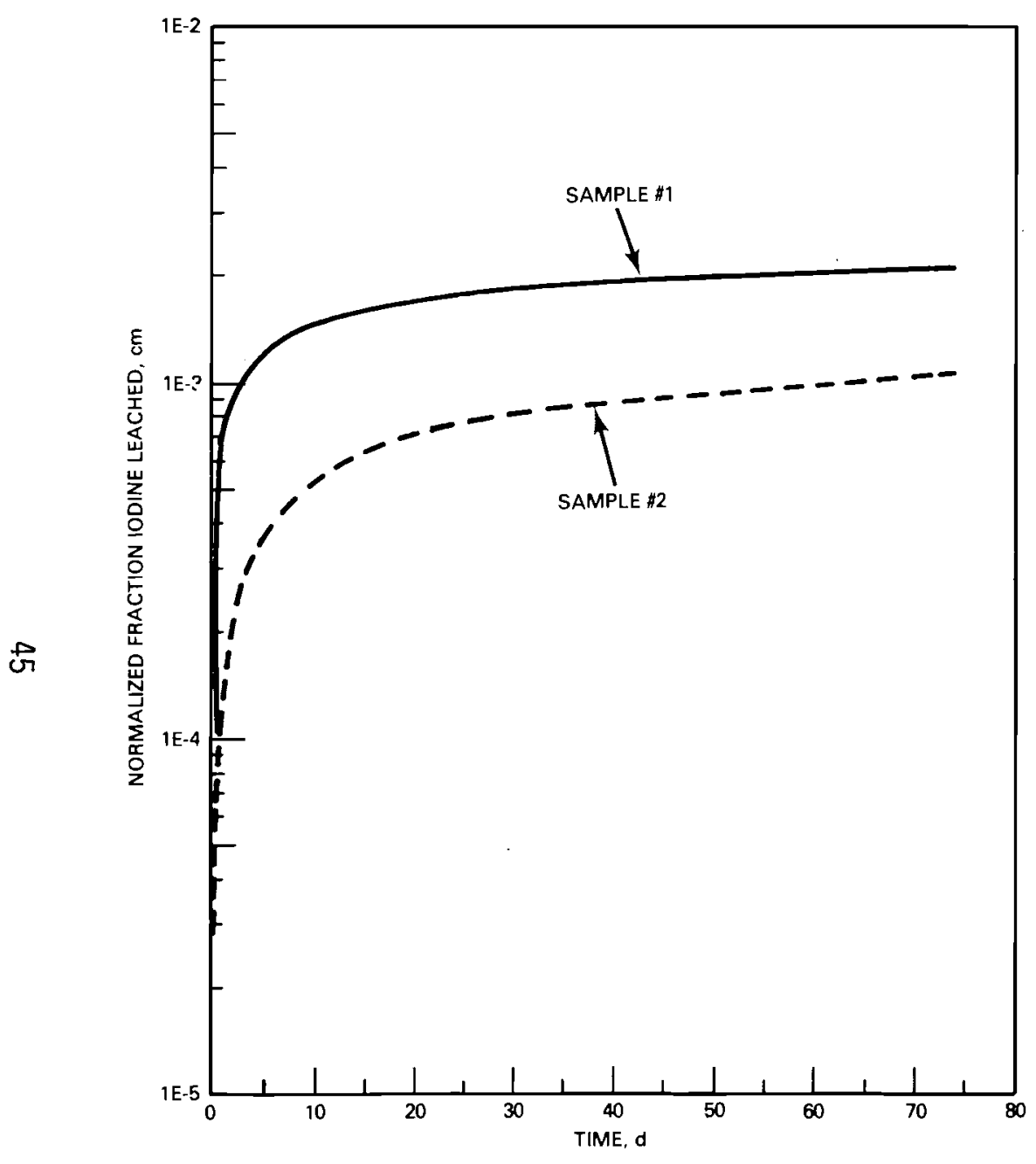

Figure 9. Simulated Dynamic Leach Test of $150 \mathrm{mg} \mathrm{I} / \mathrm{g} \mathrm{AgZ}$ in Portland Type III Cement, $0.8 \mathrm{mmol} \mathrm{I} /(\mathrm{g}$ Dry Cement + AgZ) (Distilled Water Leachate)

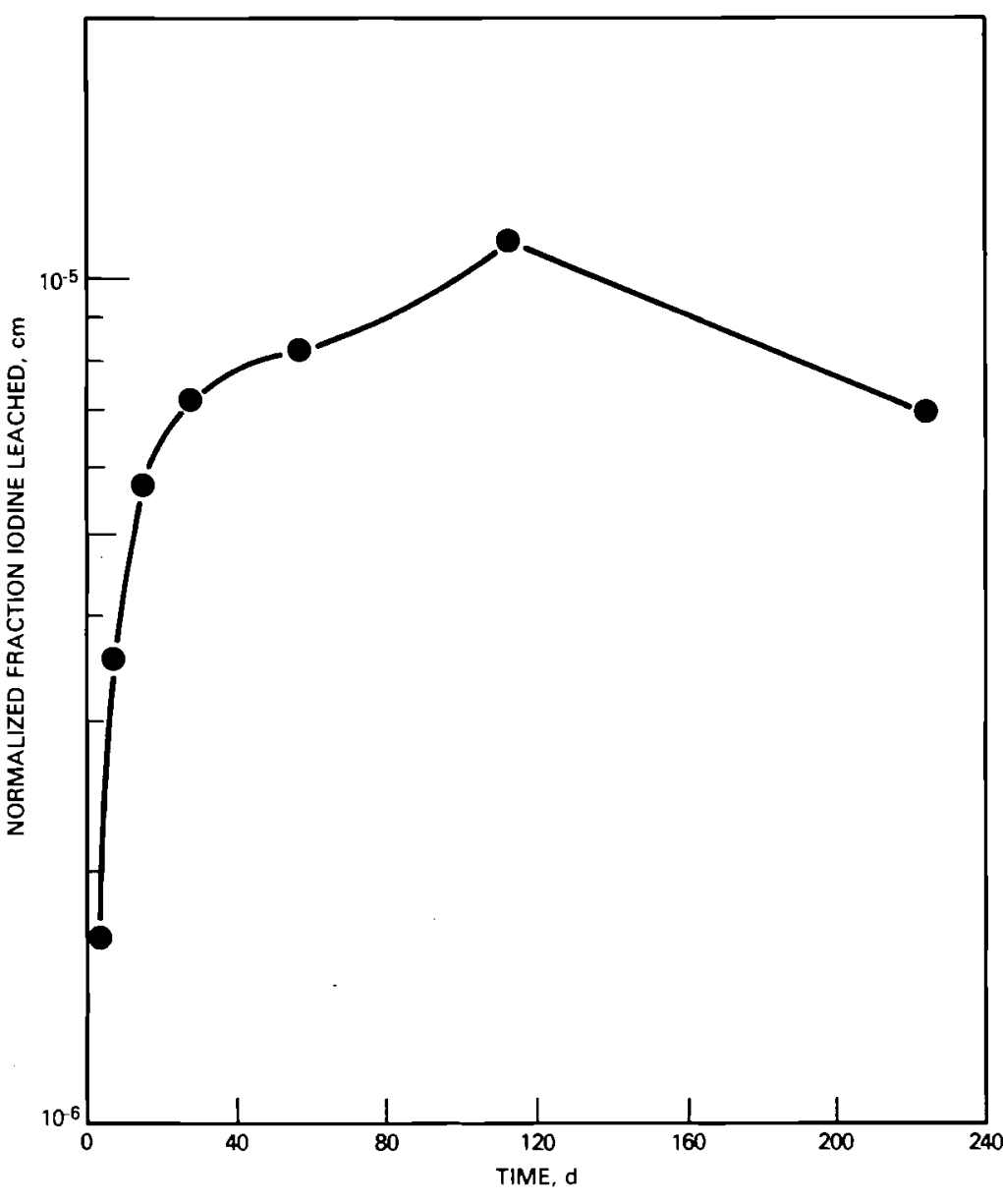

FIGURE 10. Static Leach Test of Iodine Sodalite, $1.5 \mathrm{mmol} \mathrm{I} / \mathrm{g}$ (Distilled Water Leachate) 



\section{ACKNOWLEDGMENTS}

We would like to thank C. L. Matsuzaki and D. L. McMakin for their help in the laboratory, M. K. Powell and L. D. Maki for typing the report, and J. A. Powell for her editorial assistance. 
- 


\section{REFERENCES}

Ackley, R. D. and J. Combs. 1973. Applicability of Inorganic Sorbents for Trapping Radioiodine from LMFBR Fuel Reprocessing Off-Gas. ORNL/TM-4227, Oak Ridge National Laboratory, Oak Ridge, Tennessee.

Barin, I., and 0. Knacke. 1973. Thermochemical Properties of Inorganic Substances. Springer Verlag, New York, New York.

Barin, I., 0. Knacke, and 0. Kubaschewski. 1977. Thermochemical Properties of Inorganic Substances, Supplement 1. Springer Verlag, New York, New York.

Bureau of Mines, U. S. Dept. of the Interior. 1975. Mineral Facts and Problems, Bulletin 667, Bicentennial Edition, Government Printing Office, Washington, D.C.

Bureau of Mines, U. S. Dept of the Interior. 1977. Commodity Data Summaries, Government Printing Office, Washington, D.C.

Burger, L. L. and R. E. Burns. 1979. Technical Requirements for the Control of ${ }^{129}$ I in a Nuclear Fuels Reprocessing Plant, PNL-3186, Pacific Northwest Laboratory, Richland, Washington.

Burger, L. L. 1980. Determining Criteria for the Disposal of Iodine-129, PNL-3496, Pacific Northwest Laboratory, Richland, Washington.

Burger, L. L. and R. D. Scheele. 1981. "Iodine Fixation Studies at the Pacific Northwest Laboratory," PNL-SA-9829. Paper presented at the Specialists Meeting on Radioiodine Management, September 25, 1981 , Brussels, Belgium.

Burns, R. E. and J. G. Defield. 1978. Disposal of Radioactive Iodine in Space. NASA Technical Paper 1313, Marshall Space Flight Center, Alabama. Chemical Marketing Reporter. August 31, 1981. 
Clark, W. E. 1977. "The Isolation of Radioiodine with Portland Cement. Part 1: Scoping Leach Studies," Nuc. Tech. 36:215-221.

Clark, W. E. and W. B. Howerton. 1980. "The Fixation of Radioiodine with Portland Cement. Part II: Radiation Stability Tests." Nuc. Tech. 49:209-13.

Code of Federal Regulations, Title 10, Part 20, Appendix B, Office of the Federal Register, General Services Administration, Washington, D.C., January $1,1978$.

Code of Federal Regulations, Title 40, Part 190, "Environmental Radiation Protection Standards for Nuclear Power Operations," Federal Register, 42(9) :2858-2861, January 13, 1977.

Collins, E. D. and D. E. Benker. 1979. Iodox Process Tests in a Transuranium Element Production Campaign. ORNL/TM-6182, Oak Ridge National Laboratory, Oak Ridge, Tennessee.

Dean, J. A. 1973. Lange's Handbook of Chemistry. Eleventh Ed., McGraw-Hill Book Company, New York, New York.

Duval, C. 1963. Inorganic Thermogravimetric Analysis. Trans. R. E. Desper. Elsevier Publishing Company, New York, New York.

Ga1, I. J. et a1. 1974. "Adsorption of Methyl Iodide on Impregnated Alumina." In Proceedings of the 13th AEC Air Cleaning Conference. CONF740807 .

Ginnow, R. J. and W. E. Clark. 1978. Iodox Recycle Scoping Studies of the Solubilities of Iodic Acid and of Vapor-liquid Equilibria in the System; 60 to $80 \% \mathrm{Mg}\left(\mathrm{NO}_{3}\right)_{2}-0$ to $20 \% \mathrm{HNO}_{3}-20$ to $40 \% \mathrm{H}_{2} \mathrm{O}$. ORNL/TM-6398, Oak Ridge National Laboratory, Oak Ridge, Tennessee. 
Godbee, H. W. and D. S. Joy. 1974. Assessment of the Loss of Radioactive Isotopes from Waste Solids to the Environment. Part I, Background and Theory. ORNL-TM-4333, Oak Ridge National Laboratory, Oak Ridge, Tennessee.

Holladay, D. W. 1979. A Literature Survey: Methods for the Removal of Iodine Species from Off-Gases and Liquid Waste Streams of Nuclear Power and Fuel Reprocessing Plants with Emphasis on Solid Sorbents. ORNL/TM6350, Oak Ridge National Laboratory, Oak Ridge, Tennessee.

Horner, D. E., J. C. Mailer, and H. R. Bigelow. 1976. "Solubility of PdI 2 in Nitrate and Perchlorate Solutions.", CONF-761002-4, pp. 1-24.

IAEA. 1980. Radioiodine Removal in Nuclear Facilities. IAEA Technical Reports Series 201, International Atomic Energy Agency, Vienna.

IAEA. 1981. Packaging of Radioactive Wastes for Sea Disposal. IAEA-TECDOC240, International Atomic Energy Agency, Vienna.

Jubin, R. T. 1979. A Literature Survey of Methods to Remove iodine from 0ffGas Streams Using Solid Sorbents. ORNL/TM-6607, Oak Ridge National Laboratory, Oak Ridge, Tennessee.

Latimer, W. M. 1956. Oxidation Potentials. Second Edition. Prentice-Hall, Inc., Englewood Cliffs, New Jersey.

Morgan, M. T., J. G. Moore, H. E. Devaney, G. C. Rogers, C. Williams, and E. Newman. 1978. "The Disposal of I-129." Paper presented at the Symposium on Science Underlying Radioactive Waste Management, November 28 December 1, 1978, Boston, Massachusetts.

Partridge, J. A. and G. P. Bosuego. 1979. Waste Management of Mercuric Nitrate Off-Gas Scrubber Solution. A Laboratory Study. HEDL-TME 79-11, Hanford Engineering Development Laboratory, Richland, Washington. 
Pence, D. T., F. A. Duce, and W. J. Maeck. 1971. Metal Zeolites Iodine Adsorption Studies. IN-1455, Allied Chemical Corporation, Idaho Falls, Idaho

Rieck, H. G. and J. S. Fruchter. 1975. Waste Management Alternatives for ${ }^{99}$ TC and ${ }^{129}$ I. Pacific Northwest Laboratory, Richland, Washington.

Russel1, J. L. and P. B. Hahn. 1971. "Public Health Aspects of Iodine-129 from the Nuclear Power Industry." Radiol. Health Data Rep. 12:189.

Scheele, R. D. 1978a. "Carbon-14 and Iodine-129 Fixation". Nuclear Waste Management Quarterly Progress Report April through June 1978. Eds. A. M. Platt, J.A. Powel1. PNL-2378-2, Pacific Northwest Laboratory, Richland, Washington.

Scheele, R. D. 1978b. "Carbon-14 and Iodine-129 Fixation." Nuclear Waste Management Quarterly Progress Report July through September 1978. Eds. A. M. Platt, J. A. Powe11. PNL-2378-3, Pacific Northwest Laboratory, Richland, Washington.

Scheele, R. D. 1979. "Carbon-14 and Iodine-129 Fixation." Nuclear Waste Management Quarterly Progress Report January through March 1979. Eds. A. M. Platt, J. A. Powel1. PNL-3000-1, Pacific Northwest Laboratory, Richland, Washington.

Scheele, R. D. 1980a. "Iodine-129 Fixation." Nuclear Waste Management Quarterly Progress Report October through December 1979. Eds. A. M. Platt, J. A. Powel1. PNL-3000-4, Pacific Northwest Laboratory, Richland, Washington.

Scheele, R. D. 1980b. "Iodine-129 Fixation." Nuclear Waste Management Quarterly Progress Report April through June 1980. Eds. A. M. Platt, J. A. Powel1. PNL-3000-6, Pacific Northwest Laboratory, Richland, Washington. 
Scheele, R. D. 1980c. "Iodine-129 Fixation". Nuclear Waste Management Quarterly Progress Report July through September 1980. Eds. T. D. Chikalla, J. A. Powel1. PNL-3000-7, Pacific Northwest Laboratory, Richland, Washington.

Scheele, R. D. 1981a. "Iodine-129 Fixation. "Nuclear Waste Management Quarterly Progress Report October through December 1980. Eds. T. D. Chikalla, J. A. Powell. PNL-3000-8, Pacific Northwest Laboratory, Richland, Washington.

Scheele, R. D. 1981b. "Iodine-129 Fixation." Nuclear Waste Management Quarterly Progress Report January through March 1981. Eds. T. D. Chikalla, J. A. Powell. PNL-3000-9, Pacific Northwest Laboratory, Richland, Washington.

Scheele, R. D. 1981c. "Iodine-129 Fixation." Nuclear Waste Management Quarterly Progress Report April through June 1981. Eds. T. D. Chikalla and J. A. Powel1. PNL-3000-10, Pacific Northwest Laboratory, Richland, Washington.

Scheele, R. D. and L. L. Burger. 1980. "Fixation of Iodine-129." Nuclear Waste Management Quarterly Progress Report April through June 1980. PNL-3000-6, Pacific Northwest Laboratory, Richland, Washington.

Scheele, R. D. and L. L. Burger. 1981. "Characterization Studies of Iodine Loaded Silver Zeolites." PNL-SA-9510. Paper presented at the $182 \mathrm{~d}$ National Meeting of the American Chemical Society, August 23-28, 1981, New York, New York.

Scheele, R. D. and K. D. Wiemers. 1980. "Fixation of Iodine-129." Nuclear Waste Management Quarterly Progress Report January through March 1980. PNL-3000-5, Pacific Northwest Laboratory, Richland, Washington.

Schneider, K. J., and A. M. Platt, eds. 1974. High-Level Radioactive Waste Management Alternatives, BNWL-1900, Pacific Northwest Laboratories, Richland, Washington. 
Schwarzbach, R. and 0. Hladik. 1980. "A Filter for Removal of Radioiodine from Process Gas in the Dissolution of Aluminum-Loaded Fuel Elements in Nitric Acid in the Separatin of Fission Product Molybdenum." Radioiodine Removal in Nuclear Facilities. Tech. Report Series No. 201, International Atomic Energy Agency, Vienna.

Seide11, A. 1953. Solubilities of Inorganic and Metal Organic Compounds, Vol. 1. Third edition. D. Van Nostrand Company, Inc., New York, New York.

Smith J. D. 1973. "Arsenic, Antimony, and Bismuth" in Comprehensive Inorganic Chemistry, Vol. 2. Eds. J. C. Bailar, H. J. Emeleus, R. Nyholm, A. F. Trotman-Dickenson. Pergamon Press, New York, New York.

Staples, B. A., L. P. Murphy, and T. R. Thomas. 1976. "Airborne Elemental Iodine Loading Capacities of Metal Zeolites and a Dry Method for Recycling Silver Zeolite." In Proceedings of the 14th ERDA Air Cleaning Conference. CONF-760822.

Stromatt, R. W. 1958. Removal of Radioiodine from Purex Off-Gases with Nitric Acid and Nitric Acid-Mercuric Nitrate Solutions. USAEC Report HW-55735, Hanford Atomic Products Operation, Richland, Washington.

Thomas, T. R., B. A. Staples, L. P. Murphy, and J. T. Nichols. 1977. Airborne Elemental Iodine Loading Capacities of Metal Zeolites and a Method for Recycling Silver Zeolite. ICP-1119, Allied Chemical Corp., Idaho Falls, Idaho.

Vance, E. R., D. K. Agrawal, B. E. Scheetz, J. G. Pepin, S. D. Atkinson, and W. B. White. 1981. Ceramic Phases for Immobilization of ${ }^{129}$ I, DOE/ET/41900-9 (ESG-D0E-13354), Pennsylvania State University, University Park, Pennsylvania.

Wagman, D. D., W. H. Evans, I. Halow, V. B. Parker, S. M. Bailey, and R. H. Schumm. 1965. Selected Values of Chemical Thermodynamic Properties. Technical Notes 270-1, 270-2, 270-3, 270-4, 270-5, 270-6, National Bureau of Standards, Washington, D.C. 
Weast, R. C. 1969. Handbook of Chemistry and Physics. 50th edition. Chemical Rubber Company, Cleveland, Ohio.

Wiemers, K. D. 1978a. "Carbon-14 and Iodine-129 Fixation." Nuclear Waste Management Quarterly Progress Report October through December 1977. Eds. A. M. Platt, J. A. Powell. PNL-2377-4, Pacific Northwest Laboratory, Richland, Washington.

Wiemers, K. D. 1978b. "Carbon-14 and Iodine-129 Fixation." Nuclear Waste Management Quarterly Progress Report January through March 1978. Eds. A. M. Platt, J. A. Powell. PNL-2378-1, Pacific NorthwestLaboratory, Richland, Washington.

Wiemers, K. D. 1978c. "Carbon-14 and Iodine-129 Fixation." Nuclear Waste Management Quarterly Progress Report April through June 1978. Eds. A. M. Platt, J. A. Powel1. PNL-2378-2, Pacific Northwest Laboratory, Richland, Washington.

Wiemers, K. D. 1979a. "Carbon-14 and Iodine-129 Fixation." Nuclear Waste Management Quarterly Progress Report July through September 1978. Eds.A. M. Platt, J. A. Powe11. PNL-2378-3, Pacific Northwest Laboratory, Richland, Washington.

Wiemers, K. D. 1979b. "Carbon-14 and Iodine-129 Fixation." Nuclear Waste Management Quarterly Progress Report January through March 1979. Eds. A. M. Platt, J. A. Powell. PNL-3000-1, Pacific Northwest Laboratory, Richland, Washington.

Wiemers, K. D. 1979c. "Carbon-14 and Iodine-129 Fixation." Nuclear Waste Management Quarterly Progress Report April through June 1979. Eds. A. M. Platt, J. A. Powell. PNL-3000-2, Pacific Northwest Laboratory, Richland, Washington. 
Wiemers, K. D. 1979d. "Carbon-14 and Iodine-129 Fixation." Nuclear Waste Management Quarterly Progress Report July through September 1979. Eds. A. M. Platt, J. A. Powe11. PNL-3000-3, Pacific Northwest Laboratory, Richland, Washington.

Wilhelm, J. G. and H. Schuettelkopf. 1973. "Inorganic Absorber Materials for Trapping Fission Product Iodine." Control of Iodine in the Nuclear Industry. Technical Report Services No. 148, International Atomic Energy Agency, Vienna.

Winters, W. I. 1980. The Effect of Hot-Pressing Conditions on the Properties of Iodide Sodalite. RHO-LD-153, Rockwell Hanford Operations, Richland, WA.

Yarbro, 0. 0., G. I. Cathers et al. 1969. LMFBR Fuel Cycle Studies Progress Report for September 1969, No.7. ORNL/TM-1748, Oak Ridge National 


\section{DISTRIBUTION}

No. of

Copies

OFFSITE

UNITED STATES

A. A. Churm

DOE Chicago Patent Group

9800 South Cass Avenue

Argonne, IL 60439

27 DOE Technical Information Center

R. E. Cunningham

Office of Nuclear Safety Materials and Safeguards

Room 562

Nuclear Regulatory Commission

7915 Eastern Avenue

Silver Springs, MD 20910

3 Division of Waste Management Nuclear Regulatory Commission Washington, DC 20555

ATTN: J. B. Martin

D. B. Rohrer

R. Dale Smith

W. E. Mott

DOE Division of Environmental

Control Technology

Washington, D. C. 10545

14 DOE Nuclear Waste Management

Programs

NE-30, B-107, HQ

Washington, D. C. 10545

ATTN: C. R. Cooley

G. H. Daly

J. E. Dieckhoner

C. H. George

C. A. Heath

M. L. Lawrence

D. J. McGoff

W. E. McVey

S. Meyers/R. Romatowski

G. 0ertel

A. F. Perge

R. W. Ramsey, Jr.
No. of

Copies

D. L. Vieth

R. D. Walton

S. A. Mann

DOE Chicago Operations and Region Office

Argonne, IL 60439

J. 0 . Neff

Department of Energy

Columbus Program Office

505 King Avenue

Columbus, $\mathrm{OH} \quad 43201$

3 DOE Idaho Operations Office

550 2nd Street

Idaho Falls, ID 83401

ATTN: J. B. Whitsett

M. A. Widmayer

A. L. Lotts

Oak Ridge National Laboratory P. 0. Box $X$

Oak Ridge, TN 37830

5 Oak Ridge National Laboratory P. 0. Box $Y$

Oak Ridge, TN 37830

ATTN: R. E. Blanco

J. 0. Blomeke

D. E. Ferguson

R. T. Jubin

R. S. Lowrie

1 Los Alamos Scientific Laboratory

P. 0. Box 1663

Los Alamos, NM 87544

3 DOE Savannah River Operations Office

P. 0. Box A

Aiken, SC 29801

ATTN: E. S. Goldberg

T. B. Hindman

R. P. Whitfield 
Distr-2

No. of

Copies

4 Exxon Nuclear Idaho

P. 0. Box 2800

Idaho Falls, ID 83401

ATTN: D. L. Condotta

R. A. Brown

T. R. Thomas

File Copy

G. B. Levin

EG\&G Idaho

P. 0. Box 1625

Idaho Falls, ID 83415

S. G. Harbinson

DOE San Francisco Operations

1333 Broadway

Oakland, CA 94612

2 DOE Albuquerque Operations Office P. 0. Box 54001

Albuquerque, NM 87185

ATTN: R. Y. Lowrey

A. L. Taboas

2 Allied-General Nuclear Services

P.0. Box 847

Barnwel1, SC 29812

ATTN: J. A. Buckham

A. Williams

2 Argonne National Laboratory

9700 South Cass Avenue

Argonne, IL 60439

ATTN: J. H. Kittel

M. J. Steindler/L. E.

Trevorrow

B. Rawles

Battelle Memorial Institute

Office of Nuclear Waste Isolation

505 King Avenue

Columbus, $\mathrm{OH} 43201$

6 E.I. duPont deNemours Co.

Savannah River Laboratory

Aiken, SC 29801

ATTN: W. H. Baker

J. L. Crandall
No. of

Copies
R. G. Garvin

L. W. Meyer

S. Mirshak

J. A. Porter

R. Williams

Electric Power Research Institute $3412 \mathrm{Hill}$ view Avenue

P. 0. Box 10412

Palo Alto, CA 94304

D. M. Rosenbaum

Office of Radiation Programs

U.S. Environmental Protection Agency

1921 Jefferson Davis Highway

Arlington, VA 22202

W. F. Holcomb

Office of Radiation Programs $(A-460)$

U. S. Environmental Protection Agency

Washington, D. C. 20460

Environmental Protection Agency

Technological Assessment Division (AW-559)

Office of Radiation Programs

U. S. Environmental Protection Agency

Washington, D. C. 20460

L. H. Brooks

Gulf Energy and Environmental Systems

P. 0. Box 81608

San Diego, CA 92138

C. J. Kershner

Monsanto Research Corporation

Mound Laboratory

P. 0. Box 81608

Miamisburg, $\mathrm{OH} 45342$

J. P. Duckworth

Plant Manager

Nuclear Fuels Services, Inc.

P. 0. Box 124

West Valley, NY 14171 


\section{Distr-3}

No. of

Copies

J. L. Larocca, Chairman

Engineering Research and Development Authority

Empire State Plaza

Albany, NY 12223

J. D. Tewhey

Lawrence Livermore Laboratory

P. 0. Box 808

Livermore, CA 94550

4 Sandia Laboratories

Albuquerque, NM 87185

ATTN: D. R. Anderson

0 . E. Jones

R. G. Kepler

W. Weart

J. W. Bartlett

The Analytical Sciences Corp.

6 Jacob Way

Reading, MA 01867 .

R. G. Post

College of Engineering

University of Arizona

Tucson, AZ 85721

L. L. Hench

Dept. of Materials Science and Engineering

University of Florida

Gainesville, FL 32611

G. E. Benedict

General Atomics Co.

P. 0. Box 81608

San Diego, CA 92138

R. Roy

202 Materials Research Laboratory

University Park, PA 16802

F. K. Pitman

3508 Sagecrest Terrace

Ft. Worth, TX 76109
ONSITE

No. Of

Copies

3 DOE Richland Operations Office

E. A. Bracken

H. E. Ransom

J. J. Schreiber

13 Rockwel1 Hanford Operations

H. Babad

D. R. Gustavson

R. G. Johnston

J. 0. Honeyman

E. J. Kosiancic

L. P. McRae

I. E. Reep

J. H. Roecker

W. W. Schulz

J. R. Wetch

W. I. Winters

D. D. Wodrich

File Copy

UNC United Nuclear Industries

T. E. Dabrowsk $i$

3 Westinghouse Hanford Company

A. G. Blasewitz

G. L. Richardson

J. A. Partridge

75 Pacific Northwest Laboratory

W. F. Bonner

F. P. Brauer

L. A. Bray

L. L. Burger (15)

D. B. Cearlock

T. D. Chikalla

F. H. Dove

H. Drucker

C. E. Elderk in

A. J. Haverfield/W. R. Wiley

0. F. Hill

J. H. Jarrett

A. B. Johnson, Jr.

M. R. Kreiter

L. T. Lakey 


\section{Distr-4}

R. P. Marshat 1

J. L. McElroy

R. W. McKee

J. E. Mende 1

I. C. Nelson

J. M. Nielsen/R. W. Perkins

R. E. Nightingale

A. M. Platt

J. V. Robinson

W. A. Ross/R. D. Nelson

J. M. Rusin

R. D. Scheele (15)

R. J. Serne

J. K. Soldat

J. L. Swanson

G. L. Tingey

C. M. Unruh

H. H. Van Tuy 1

B. E. Vaughan

E. C. Watson

E. J. Whee Iwright

K. D. Wiemers

C. R. Hann

A. M. Sutey

D. E. Olesen

Technical Information (5)

Publishing Coordination (2) 